OPEN ACCESS

Edited by:

Santi M. Mandal,

Indian Institute of Technology

Kharagpur, India

Reviewed by:

Piyush Baindara,

University of Missouri, United States

Md. Tanvir Rahman,

Bangladesh Agricultural University,

Bangladesh

Farhad Safarpoor Dehkordi,

University of Tehran, Iran

${ }^{*}$ Correspondence:

Samer Singh

samer.singh10@bhu.ac.in

Specialty section

This article was submitted to Antimicrobials, Resistance

and Chemotherapy,

a section of the journal

Frontiers in Microbiology

Received: 07 July 2020 Accepted: 18 September 2020 Published: 05 November 2020

Citation:

Singh AK, Das S, Kumar S, Gajamer VR, Najar IN, Lepcha YD,

Tiwari HK and Singh S (2020)

Distribution of Antibiotic-Resistant

Enterobacteriaceae Pathogens

in Potable Spring Water of Eastern

Indian Himalayas: Emphasis on

Virulence Gene and Antibiotic

Resistance Genes in Escherichia coli.

Front. Microbiol. 11:581072.

doi: 10.3389/fmicb.2020.581072

\section{Distribution of Antibiotic-Resistant Enterobacteriaceae Pathogens in Potable Spring Water of Eastern Indian Himalayas: Emphasis on Virulence Gene and Antibiotic Resistance Genes in Escherichia coli}

\author{
Ashish Kumar Singh ${ }^{1}$, Saurav Das², Santosh Kumar', Varsha Rani Gajamer1, \\ Ishfaq Nabi Najar', Yangchen D. Lepcha ${ }^{3}$, Hare Krishna Tiwari' and Samer Singh ${ }^{4 *}$

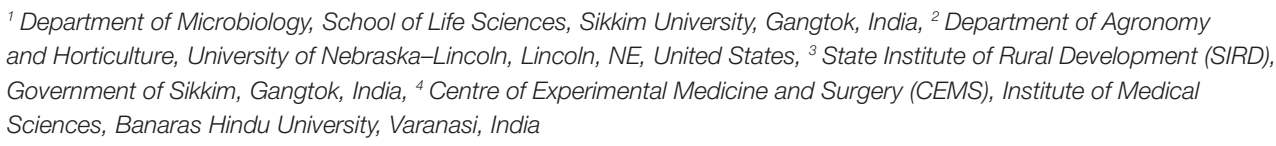
and Horticulture, University of Nebraska-Lincoln, Lincoln, NE, United States, ${ }^{3}$ State Institute of Rural Development (SIRD), Government of Sikkim, Gangtok, India, ${ }^{4}$ Centre of Experimental Medicine and Surgery (CEMS), Institute of Medical Sciences, Banaras Hindu University, Varanasi, India

Every year millions of people die due to fatal waterborne diseases around the world especially in developing countries like India. Sikkim, a northeastern state of India, greatly depends on natural water sources. About $80 \%$ of the population of Sikkim depends on natural spring water for domestic as well as agricultural use. Recent waterborne disease outbreaks in the state raises a concerning question on water quality. In this study, we analyzed water quality especially for the detection of Enterobacteriaceae members from four districts of the state. Isolation with selective culture media techniques and taxonomic characterization of Enterobacteriaceae bacteria with 16S rRNA gene showed the prevalence of Escherichia coli (37.50\%), Escherichia fergusonii (29.41\%), Klebsiella oxytoca (36.93\%), Citrobacter freundii (37.92\%), Citrobacter amalonaticus (43.82\%), Enterobacter sp. (43.82\%), Morganella morganii (43.82\%), Hafnia alvei (32.42\%), Hafnia paralvei (38.74\%), and Shigella flexneri (30.47\%) in the spring water of Sikkim. Antibiotic susceptibility test (AST) showed resistance of the isolates to common antibiotics like ampicillin, amoxicillin as well as to third generation antibiotics like ceftazidime and carbapenem. None of the isolates showed resistance to chloramphenicol. E. coli isolated from spring water of Sikkim showed presence of different virulence genes such as stx1 (81.81\%), elt (86.66\%), and eae (66.66\%) along with resistance gene for ampicillin (CITM) (80\%), quinolones (qnrB) (44.44\%), tetracycline (tetO) (66.66\%), and streptomycin (aadA1) (66.66\%). The data indicates a high incidence rate of multiple antibiotic resistant enteric bacteria in the spring water of Sikkim. Additionally, the presence of enteric bacteria in the water samples indicates widespread fecal contamination of the spring water.

Keywords: spring, Enterobacteriaceae, virulence gene, antibiotic resistance gene, multidrug resistant (MDR), water quality, waterborne pathogens 


\section{INTRODUCTION}

Water is important for every facet of life (Mishra et al., 2018). Surface water acts as a natural source of freshwater and is important for drinking, cooking as well as other household purposes (Vaz-Moreira et al., 2013). Approximately one-third of global freshwater reserves are subsurface streams (Hemme et al., 2015). Safe and clean drinking water is a basic right to every human being for a healthy life. Globally freshwater is becoming a limited resource due to population expansion, anthropoegenic contamination and climate change (Hassan Rashid et al., 2018). Contaminated water can cause several illnesses including dysentery, cholera, diarrhea, typhoid, and in chronic cases leading to loss of life on a normal basis especially in developing countries. Due to lack of quality health care systems and insufficiency in the supply of pure potable water, developing countries are on the alarming list of waterborne disease outbreaks (World Health Organisation, 2018). It is reported that $80 \%$ of the diseases worldwide occurs due to contaminated water and water borne pathogens (Haseena et al., 2017). Diarrhea alone is the cause of 8,42,000 deaths every year and by 2025 half of the world is expected to be living in the water stressed areas increasing the risks of dying from waterborne diseases (World Health Organisation, 2018).

Antibiotic resistance is responsible for thousands of death annually and which is projected to increase dramatically as a global health hazard (Momtaz et al., 2013; Adzitey, 2020). It is estimated that antibiotic resistance might lead to ten million deaths annually by 2050 (Bengtsson-Palme et al., 2018; Praveenkumarreddy et al., 2020). Treatment of infectious diseases has been revolutionized since the discovery, production and use of antimicrobial substances (Stange et al., 2016). However, the misuse of antimicrobial substances are the major cause of emergence of antibiotic resistance in pathogenic bacteria (Singh et al., 2018a; Meng et al., 2020). Most of the antibiotics provided to humans for household purpose ends up in the sewage system from excretion and finally to water sources (Karkman et al., 2018). Studies reported that after consumption of drugs, a significant portion $(50-90 \%)$ of antibiotics excreted by humans in domestic sewage systems remains unchanged keeping its chemical properties sufficient to meet the therapeutic use (Costa and Arpini, 2016). Chemical properties of drugs poses a potential risk to public health and environment as their resistant components are difficult to decompose (Costa and Arpini, 2016). Our ecosystem is constantly exposed to a wide variety of antimicrobials through wastewater treatment plants, agricultural runoff as well as animal-related and anthropogenic bustle (Baquero et al., 2008; Anand et al., 2016). The sewage treatment plants contain a large number of antibiotic resistant bacteria (ARB) with antibiotic resistance genes (ARGs) which get discharged into water bodies. Use of untreated water from these bodies, increases the probability of public health risks due to them acting as a source of ARB and ARGs (Stange et al., 2016; Bengtsson-Palme et al., 2018; Obayiuwana and Ibekwe, 2020). Contaminated water provides a perfect selective and natural media for interaction between ARB and environmental bacteria for the horizontal shift of ARGs (Anand et al., 2016). The presence of ARGs in human pathogens imposes a negative effect on health including failure of treatments, prolonged treatment periods, and in chronic cases deaths (Bueno et al., 2018). It is reported that about 7,00,000 peoples die each year due to the infection of ARB and that may increase up to 10,000,000 peoples per year by 2050 (Na et al., 2018; Morris and Cerceo, 2020).

Water quality assessment is the need of this hour to predict and minimize the future risks of water-borne diseases especially in rural areas of developing countries. Commensal bacteria living in the gastrointestinal tract of humans and animals mostly from Enterobacteriaceae family are used as a microbiological indicator of water quality and fecal contamination (Stange et al., 2016; Adegoke et al., 2020). There are several common fecal coliform genera such as Escherichia, Klebsiella, Citrobacter, Enterobacter, Morganella, and Hafnia (Stange et al., 2016). Escherichia coli is a key member of the Enterobacteriaceae family, lives commensally in the gastrointestinal tract without causing any infections. However, acquisition of virulence gene (VG) and ARGs by E. coli can cause a wide range of intestinal and extra-intestinal infections including diarrhea, urinary tract infection, and meningitis (Stange et al., 2016; Subbiah et al., 2020). Emergence and spreading of new antibiotic resistance in the Enterobacteriaceae family is becoming a major risk to clinical facilities to treat common infections. Without a comprehensive understanding of the future health risk, it can put us back into the pre-antibiotic era where common infections and minor injuries can become fatal again.

Sikkim $\left(27^{\circ} 05^{\prime}\right.$ to $28^{\circ} 07^{\prime} \mathrm{N}$ latitudes and $87^{\circ} 59^{\prime}$ to $88^{\circ}$ $56^{\prime}$ E longitudes), an Eastern Himalayan state of India, lies between Nepal and Bhutan (Tambe et al., 2013). The state faces a tremendous scarcity of potable and treated drinking water for the rural as well as urban population. Though the Himalayan range is a source of countless perennial rivers, Sikkimese people largely depend on spring water for their sustenance. The mountain springs, locally known as "Dharas," are the natural discharges of groundwater from various aquifers (Tambe et al., 2012, 2013). About $80 \%$ of the total rural community is solely dependent on spring water for their domestic and potable purpose (Tambe et al., 2012; Singh et al., 2018a, 2019). Sikkimese people use untreated spring water for their daily uses which is a major threat to public health, as these could serve as a reservoir of waterborne pathogens (Tambe et al., 2013). The dependence of the people of the state on spring water solely defines the importance of this study. This study reports the distribution of Gram-negative bacteria in spring water, and their VGs, and ARGs from four districts viz. East (E), West (W), South (S), and North (N). Lack of such previous reports makes it an important foundation for structuring and devising the future water treatment protocols and for revising and restructuring the government policies to tackle future health risks.

\section{MATERIALS AND METHODS}

\section{Description of Study Site}

The study was conducted in different villages of Sikkim, which is a NorthEastern state of India. The State is located off 
the slopes of Eastern Himalayas between the latitude of $27^{\circ}$ $05^{\prime}$ and $28^{\circ} 07^{\prime}$ North and the longitudes of $87^{\circ} 59^{\prime}$ and $88^{\circ} 56^{\prime}$ East, covering approximately $115 \mathrm{~km}$ from North to South and $65 \mathrm{~km}$ from East to West. The landscape of this area varies with an altitude between 300 to $8583 \mathrm{~m}$ above sea level that comprises lower, middle and higher hills, alpine zones and snowbound land. Sikkim is a multi-ethnic state comprising of both tribal and non-tribal groups (Tambe et al., 2012). The Himalayan range is one of the important sources of numerous perennial rivers and springs (Tambe et al., 2012) (Figure 1).

\section{Study Design}

For the current study, a total of 40 spring water samples (10 samples $\times 4$ districts $=40$ samples) were collected from four districts. Springs were selected based on the prevelance of waterborne diseases in a particular area with the help of the State Institute of Rural Development (SIRD), Government of Sikkim, India. The SIRD department helped in selecting the particular area of different districts, community, and blocks (village level blocks: VLB or Gram Panchyant Unit: GPU) which reported recent waterborne disease outbreaks. More than $80 \%$ of the springs water samples in that particular area were collected for microbiological and antibiotic resistance analysis. Springs were further selected based on the number of population dependent, altitude and perennial nature. Selection of perennial nature was based on the reason that those spring water will be used by the community throughout the year and large number of population will be depended. Higher the number of population dependency there will be higher risk of anthropoegenic contamination. Easy accessibility of springs at lower altitude could also be major contributing factor for water contamination (Supplementary File S1). The complete study design is summarized in Supplementary File S2.

\section{Sampling Procedure}

Water samples were collected in 1L sterile, wide-mouth, plastic bottles (Nalgene, United States). Before collection, containers were sterilized by autoclaving and washed with aqueous sodium thiosulfate solution $[100 \mathrm{~g} / \mathrm{l}(\mathrm{w} / \mathrm{v})]$. While collecting the samples, bottles were completely submerged into the water and it was opened inside the water source to avoid air contamination. Containers were filled by holding it diagonally; lower part was submerged up to $30 \mathrm{~cm}$ with the mouth facing slightly upwards. A gap of $2 \mathrm{~cm}$ was left between the cap and water to provide sufficient airspace for the mixing of water before analysis (American Public Health Association, 1999).

\section{Enrichment of Water Sample}

One milliliter of water samples were enriched in different enrichment media like Lauryol Tryptose Broth (Hi-media, M080), Gram-Negative Broth (Hi-media, N242), Selenite Cystine broth (Hi-media, M1079) and Alkaline Peptone Water (Himedia, M618) and incubated at $37^{\circ} \mathrm{C}$ for overnight (American Public Health Association, 1999).

\section{Isolation of Bacteria}

For isolation of bacteria, one loop full of enriched media was inoculated on different culture media like MacConkey and Eosin-Methylene Blue for isolation of Escherichia coli, Klebsiella, Enterobacter, Hafnia, Morganella, and Citrobacter. SalmonellaShigella agar was used for the isolation of Salmonella and Shigella species. Thiosulfate Citrate Bile Salt agar was used for the isolation of Vibrio species (Murray et al., 2017).

\section{Identification of Bacteria}

The isolates were identified by colony morphology, cell morphology and standard biochemical test as recommended in the Manual of Clinical Microbiology (Supplementary Files S3, S4) (Murray et al., 2017). Colony and cell morphology were summarized in Supplementary File S3. Gram staining method was used for cell morphology and different standard biochemical tests such as IMViC Test, different sugar fermentation test, amino acid metabolism tests were performed for identification of bacterial isolates (Supplementary File S4).

\section{Antibiotic Susceptibility Test}

The antibiotic susceptibility test (AST) was performed using different classes of antibiotics viz. ampicillin (30 mcg, cat no. SD077, Hi-media), amoxicillin (30 mcg, cat no. SD0076, Himedia), cefoxitin (30 mcg, cat no. SD041, Hi-media), ceftazidime (30 mcg, cat no. SD062, Hi-media), streptomycin (10 mcg, cat no. SD031, Hi-media), netillin (30 mcg, cat no. SD046, Hi-media), amikacin (30 mcg, cat no. SD035, Hi-media). Chloramphenicol (30 mcg, cat no. SD006, Hi-media), tetracycline (30 mcg, cat no. SD037, Hi-media), imipenem (10 mcg, cat no. SD073, Hi-media), ciprofloxacin (5 mcg, cat no. SD060, Hi-media), norfloxacin (10 mcg, cat no. SD057, Hi-media) and ofloxacin (5 mcg, cat no. SD087, Hi-media) by disk diffusion method. Selection of these antibiotics were made based on their differences in mode of action in bacterial cell. Ampicillin, cephalosporin, and imipenem target bacterial cell wall, streptomycin; tetracyclin inhibits protein synthesis and Quinolones inhibit bacterial DNA replication. A single colony of pure bacterial isolates was inoculated in $5 \mathrm{ml}$ of sterile $\mathrm{NaCl}(0.9 \%)$ to make equivalent turbidity of McFarland 0.5 standard. After that, the suspension was evenly streaked on the Mueller-Hilton Agar (MHA) with a sterile cotton swab. The disks containing different concentrations of antibiotics were impregnated on the plate using sterile forceps (CLSI, 2014). The standard culture of E. coli MTCC10898 was used as an antibiotic sensitive control culture with each batch of AST.

The isolates which displayed resistance to three or more than three classes of antibiotics were designated as multidrug resistant (MDR) bacteria. The Multiple Antibiotic Resistance (MAR) Index was calculated by using the formula (Krumperman, 1983):

\section{MAR $=$}

Number of antibiotics to which an isolate showed resistance

Total no of antibiotics used 


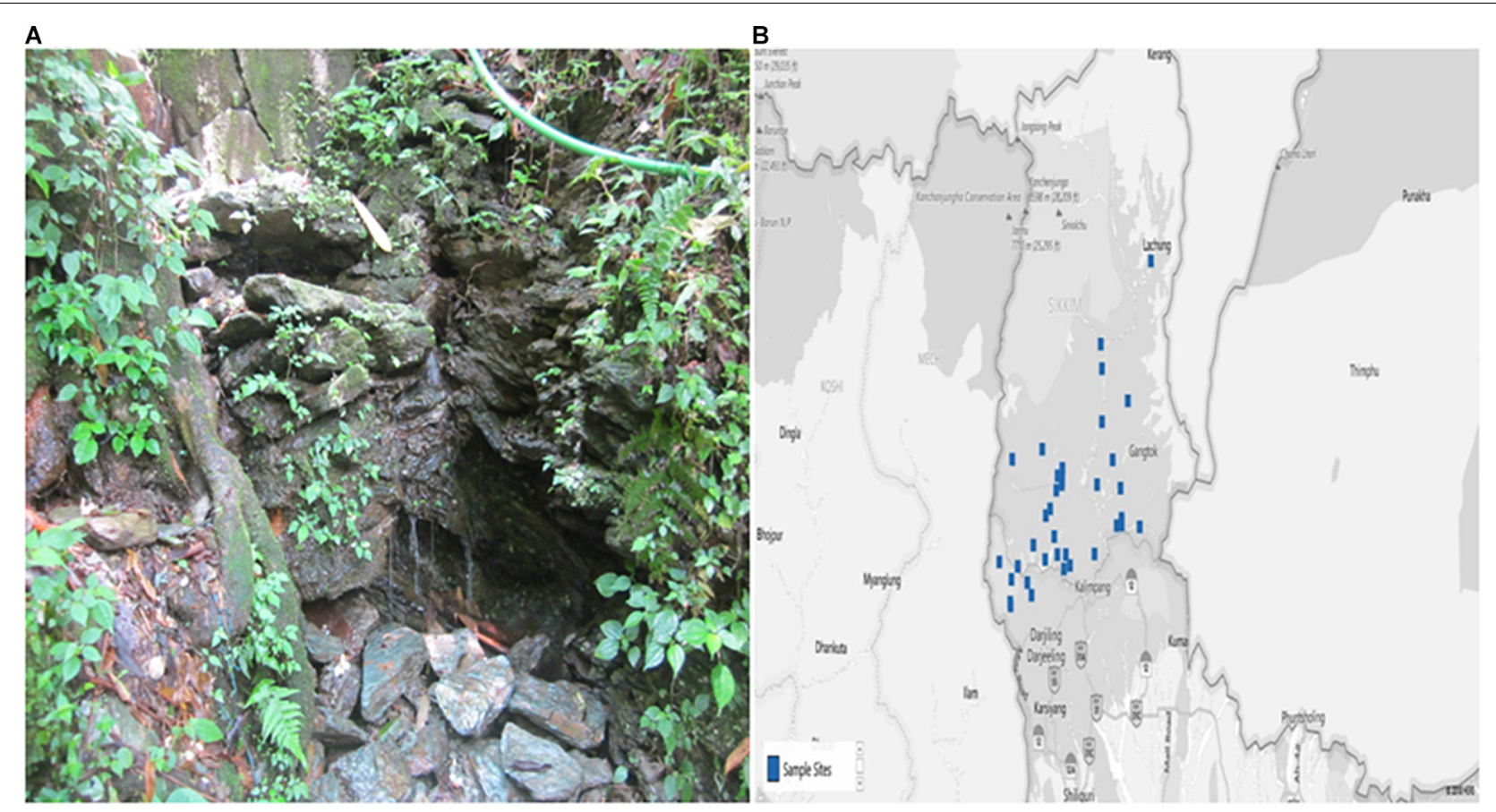

FIGURE 1 | The photograph showing (A) Spring Water and (B) Map of the study site (blue dots specify the villages from where samples were collected) as previously reported (Singh et al., 2019). The map was collected from the Spring Detail (http://www.Sikkimsprings.org/dv/view.php) [Map chart was prepared in Microsoft Excel (office 365)] (Supplementary File: Table S1).

\section{S rRNA Sequencing}

Selected bacterial isolates were identified by $16 \mathrm{~S}$ rRNA sequencing. Bacterial DNA was extracted by standard boiling lysis method. A single colony of each isolate were suspended in $100 \mu \mathrm{l}$ of double distilled water and boiled for $10 \mathrm{~min}$. After boiling, the samples were kept in ice for $10 \mathrm{~min}$, followed by centrifugation for $5 \mathrm{~min}$ at $11,200 \mathrm{~g}$ to pellet down the cellular debris. Collected supernatant was used as a template for PCR amplification of $16 \mathrm{~S} r R N A$. A total of $25 \mu \mathrm{l}$ reaction mixture was prepared with $2 \mu \mathrm{l}$ of template DNA (100 ng/ $\mu \mathrm{l}), 1 \mu \mathrm{l}$ of universal 16S rRNA primers (27F 5' $5^{\prime}$ AGAGTTTGATCMTGGCTCAG-3' and $1492 \mathrm{R} 5^{\prime}$-TACGGYTACCTTGTTACGACTT-3') (10 Pico mole) (Woo et al., 2000), $12.5 \mu \mathrm{l}$ of Go Taq Green Master Mix, $0.5 \mu \mathrm{l}$ of $2 \mathrm{X}$ DNA polymerase (Promega, Madison, United States). The volume make-up was done with nucleasefree water. Reaction cycle used for amplification was as follows: initial denaturation, $95^{\circ} \mathrm{C}$ for $3 \mathrm{~min} ; 30$ cycle of denaturation at $95^{\circ} \mathrm{C}$ for $30 \mathrm{~s}$, annealing at $54^{\circ} \mathrm{C}$ for $1 \mathrm{~min}$, extension at $72^{\circ} \mathrm{C}$ for $1.30 \mathrm{~min}$, final extension at $72^{\circ} \mathrm{C}$ for $10 \mathrm{~min}$. Quality of the DNA was checked on $0.8 \%$ agarose gel and DNA was quantified using nanodrop at 260/280 ratio. The standard culture E. coli MTCC 1089 were used as a positive control for PCR amplification of $16 \mathrm{~S}$ rRNA gene.

\section{Detection of Virulence Gene in $E$. coli by Multiplex PCR}

DNA of E. coli isolates were extracted by the Phenol-Chloroform method as described by Sambrook and Russell (2002). All the multiplex PCR reactions were performed in $20 \mu \mathrm{l}$ reaction mixture containing: template $0.5 \mu \mathrm{l}$, PCR master mix $10 \mu \mathrm{l}$ containing Taq DNA polymerase $0.05 \mathrm{U} / \mu \mathrm{l}$, reaction buffer, $4 \mathrm{mM}$ $\mathrm{MgCl}_{2}, 0.4 \mathrm{mM}$ of each dNTP (Thermo Fisher Scientific, cat. No: K0171) and $1 \mu \mathrm{l}$ of each forward and reverse primer (Eurofins Scientific, India) (Table 1). The PCR reaction conditions were as follows: $95^{\circ} \mathrm{C}$ for $2 \mathrm{~min}, 95^{\circ} \mathrm{C}$ for $15 \mathrm{~s}, 52^{\circ} \mathrm{C}$ for $8 \mathrm{~s}$ and $72^{\circ} \mathrm{C}$ for $10 \mathrm{~s}, 30$ cycles and a final extension at $72^{\circ} \mathrm{C}$ for $2 \mathrm{~min}$. Amplified products were analyzed by $2 \%$ agarose gel electrophoresis with EtBr staining. Virulent STEC strain was selected for this study based on the fact that they can cause severe food borne and water borne diseases. Secondly, primary sources of STEC outbreaks are raw or undercooked ground meat products (Hemmatinezhad et al., 2015), raw milk (Momtaz et al., 2012), and fecal contamination of vegetables (Luna-Guevara et al., 2019; Reza et al., 2019) and it has been reported from Sikkim in previous studies (Bandyopadhyay et al., 2012).

\section{Detection of Antibiotic Resistance Genes in E. coli}

Antibiotic resistance genes for tetracycline, streptomycin, quinolones, and ampicillin were detected using PCR (Table 2). A $25 \mu \mathrm{l}$ PCR reaction mixture containing $12.5 \mu \mathrm{l} 2 \mathrm{X}$ Thermo Fischer scientific master mix, $1 \mu \mathrm{l}$ of $20 \mathrm{pmol}$ of each primer i.e., forward and reverse primers (Table 2), double distilled water $(8.5 \mu \mathrm{l})$ and DNA template $(2 \mu \mathrm{l})$. PCR reaction conditions were as following: initial denaturation $95^{\circ} \mathrm{C}$ for $5 \mathrm{~min}, 35$ cycles of $95^{\circ} \mathrm{C}$ for $30 \mathrm{~s}, 52^{\circ} \mathrm{C}$ for $1 \mathrm{~min}$ and $72^{\circ} \mathrm{C}$ for $1 \mathrm{~min}$, with a final 
TABLE 1 | List of primers used for virulence gene detection, their sequence, and amplified product size.

\begin{tabular}{|c|c|c|c|c|}
\hline Target Gene & Primers & Primer designation & PCR Product Size (bp) & References \\
\hline \multirow[t]{2}{*}{ elt } & F 5'-ACGGCGTTACTATCCTCTC-3' & $\mathrm{LT}$ & 273 & Tobias and Vutukuru, 2012 \\
\hline & R 5'-TGGTCTCGGTCAGATATGTG -3’ & & & \\
\hline \multirow[t]{2}{*}{ stx1 } & F 5'-CAGTTAATGTGGTGGCGAAGG-3' & Stx1 & 348 & Tobias and Vutukuru, 2012 \\
\hline & R 5' -CACCAGACAATGTAACCGCTG-3' & & & \\
\hline \multirow[t]{2}{*}{ eae } & F 5'-TCAATGCAGTTCCGTTATCAGTT-3' & Eae & 482 & Tobias and Vutukuru, 2012 \\
\hline & R 5'-GTAAAGTCCGTTACCCCAACCTG-3' & & & \\
\hline
\end{tabular}

TABLE 2 | List of ARGs primers, their sequence, and the amplified product size.

\begin{tabular}{|c|c|c|c|c|}
\hline Target Gene & Primers & Primer designation & PCR Product Size (in bp) & References \\
\hline \multirow[t]{2}{*}{ Tetracycline } & F 5'-AACTTAGGCATTCTGGCTCAC-3' & tetO & 515 & Al-Bahry et al., 2016 \\
\hline & R 5'-TCCCACTGTTCCATATCGTCA -3' & & & \\
\hline \multirow[t]{2}{*}{ Streptomycin } & F 5'-TTTGCTGGTTACGGTGAC-3' & aadA1 & 497 & Nahar and Rashid, 2018 \\
\hline & R 5'-GCTCCATTGCCCAGTCG-3' & & & \\
\hline \multirow[t]{2}{*}{ Quinolones } & F 5'-GATCGTGAAAGCCAGAAAGG-3' & qnrB & 469 & Robicsek et al., 2006 \\
\hline & R 5'-ACGATGCCTGGTAGTTGTCC-3’ & & & \\
\hline \multirow[t]{2}{*}{ Ampicillin } & F 5'-TGGCCAGAACTGACAGGCAAA-3' & CITM & 462 & Amer et al., 2018 \\
\hline & R 5'-TाTCTCCTGAACGTGGCTGGC-3' & & & \\
\hline
\end{tabular}

extension at $72^{\circ} \mathrm{C}$ for $7 \mathrm{~min}$. Amplified products were analyzed by $1.5 \%$ agarose gel electrophoresis.

\section{Statistical Analysis}

Results were analyzed using Microsoft Excel (Office 365). The significance of the results were tested using $t$-test at $p<0.05$ between presence of bacterial diversity, antibiotic resistance pattern, ARG and virulence gene of isolates from different spring water of Sikkim. Multivariate analysis like principle component analysis (PCA) was performed to establish correlation between the diversity of antibiotic resistant pathogens in different spring water of Sikkim using $\mathrm{R}$ statistics (Package:Factoextra). Correlation between antibiotic resistance and virulence gene was tested using Pearson-correlation test with $\mathrm{R}$ statistical package "PerformanceAnalytics." One way ANOVA was used to see significance of the results and significant results were tested using post hoc Tukey's honestly significant difference (HSD) for significant pairwaise comparison. After Tukey HSD, $p$-value was adjusted with Tukey correction factor. ANOVA and post hoc Tukey was analyzed using $\mathrm{R}$ statistics (package: rstatix and ggpubr).

\section{RESULTS}

\section{Microbial Diversity}

Among the total 440 bacterial isolates, $10 \%$ of bacterial isolates were not representative of any clinically important pathogens and were not considered in this study. Out of 400 clinically important bacterial isolates, a total of $36.36 \%$ were isolated from South Sikkim, 32.95\% from East Sikkim, West Sikkim 18.18\% and $12.50 \%$ from North Sikkim. All the spring water samples were positive for one or more Enterobacteriaceae isolates. The bacterial isolates were identified by colony morphology and cell morphology. All the 400 identified medically important bacteria (90\%) were Gram-negative, rod-shaped bacteria, and belonged to Enterobacteriaceae family [90.90\%, $p<0.05(p=0.03)]$. Molecular characterization using $16 \mathrm{~S}$ rRNA sequencing showed dominance of the phylum. The Enterobacteriaceae family members were predominant in all the water samples of Sikkim. Among the 400 clinically important bacteria isolated from different districts, Citrobacter amalonaticus [18.18\%, $p>0.05$, $(p=0.92)]$, Enterobacter sp. [18.18\%, $p>0.05,(p=0.92)]$, and Morganella morganii [18.18\%, $p>0.05,(p=0.92)]$ were predominant followed by Escherichia fergusonii [13.79\%, $p>0.05,(p=0.92)]$ and Hafnia alvei $[13.79 \%, p>0.05$, $(p=0.92)]$. District wise bacterial diversity showed that East Sikkim was mainly dominated by Hafnia alvei [13.79, $p>0.05,(p=0.92)]$ and Escherichia fergusonii $[13.79, p>0.05$, $(p=0.0001)]$ whereas South Sikkim was dominated by Shigella flexneri $[10 \%, p<0.05,(p=0.92)]$. The Citrobacter amalonaticus $[12.5 \%, p>0.05,(p=0.92)]$, Enterobacter spp. $[12.5 \%, p>0.05$, $(p=0.92)]$ and Morganella morganii $[12.5 \%, p>0.05,(p=0.92)]$ were dominant in the West Sikkim whereas North Sikkim was dominated by Citrobacter amalonaticus [18.18\%, $p>0.05,(p$ $=0.92)]$, Enterobacter spp. [18.18\%, $p>0.05,(p=0.92)]$ and Morganella morganii [18.18\%, $p>0.05,(p=0.92)$ ] (Figure 2). All the 16S rRNA sequences were submitted to NCBI and accession number were summarized in Supplementary File S5 and Figure 3.

\section{Antibiotic Resistance in the Bacterial Isolates of Spring Water of Sikkim}

Identified bacterial isolates were further subjected to AST (Supplementary File S6). Citrobacter freundii isolates were highly resistant to ampicillin (75\%). Escherichia fergusonii isolates were resistant to ceftazidime (73.30\%). Escherichia coli isolates were resistant against both ampicillin (66.66\%) and 


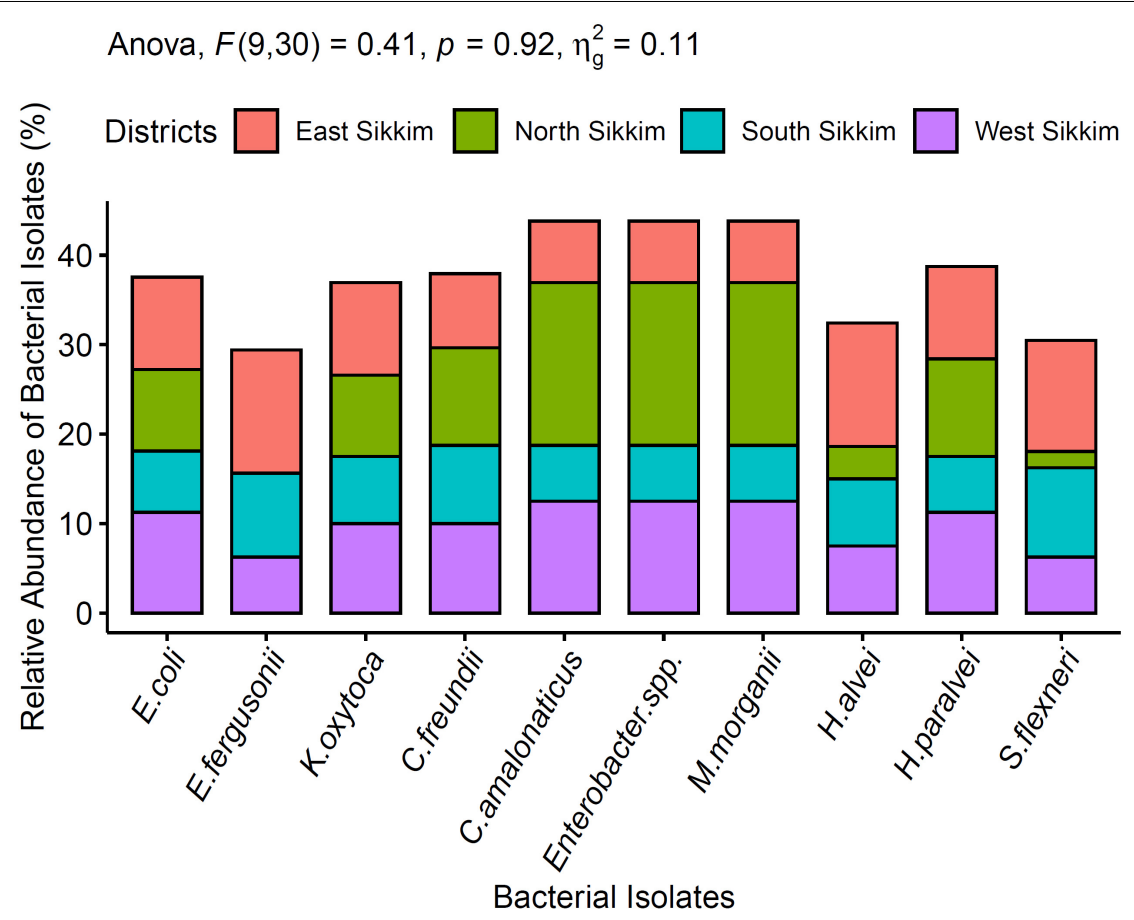

pwc: Tukey HSD; p.adjust: Tukey

FIGURE 2 | Dominant bacteria present in the spring water of Sikkim. ANOVA didn't show any significant difference between the data.

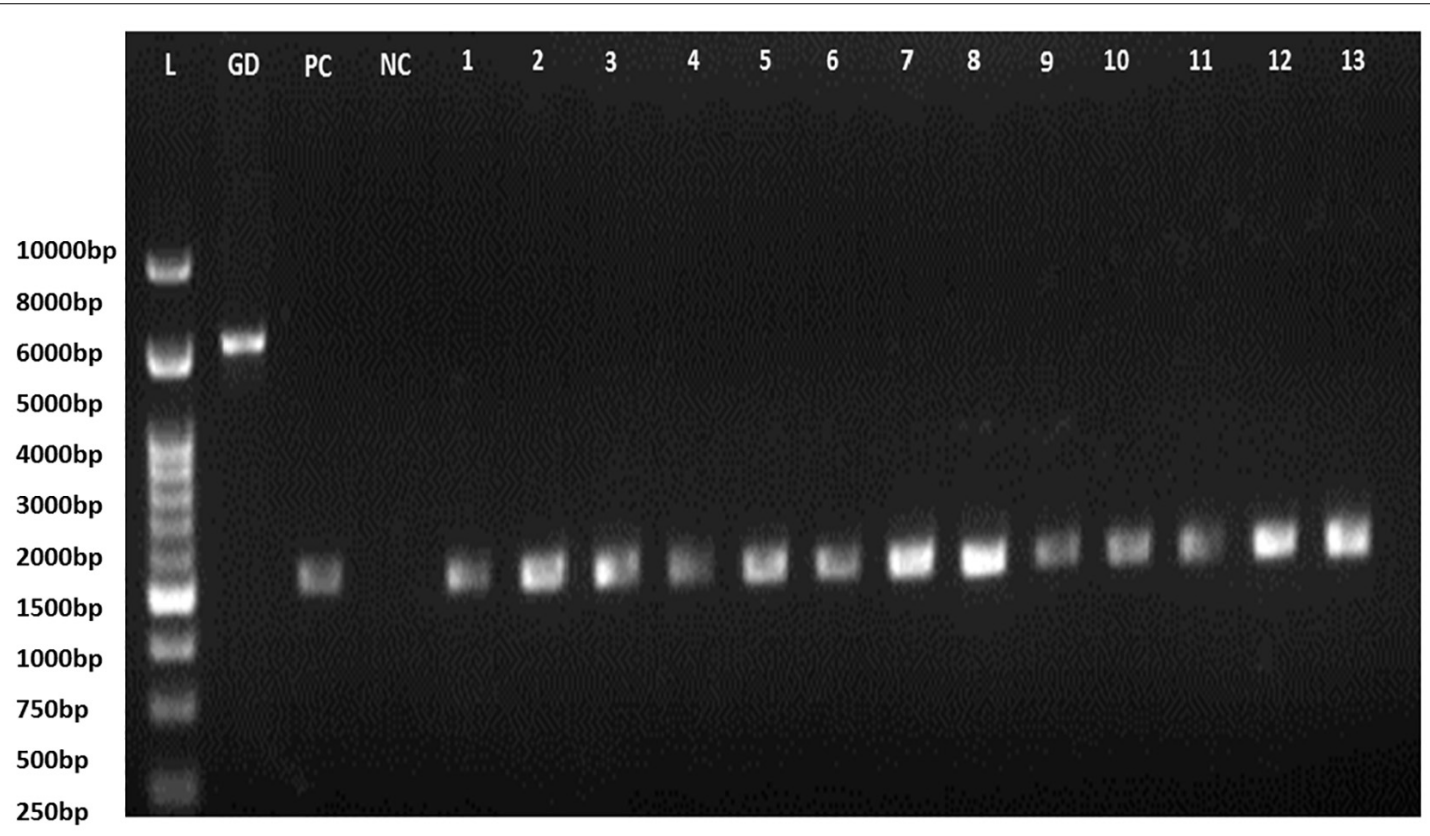

FIGURE 3 | 16S rRNA PCR gel electrophoresis (L, Ladder; GD, Genomic DNA; PC, positive control of E. coli amplified product; NC, Negative control; 1-13: isolates code).

amoxicillin $(66.66 \%)$ and Klebsiella oxytoca isolates were resistant against cefoxitin $(66.66 \%)$. The least resistance was found against ofloxacin $(5.55 \%)$ by Shigella flexneri (Figure 4). Antibiotic resistance was recorded in following order (decreasing order): ampicillin, amoxicillin, cefoxitin, ceftazidime, streptomycin, amikacin, tetracycline, netillin, ciprofloxacin, norfloxacin, imipenem and ofloxacin. Bacterial isolates from East Sikkim showed resistance against highest number of antibiotics followed 


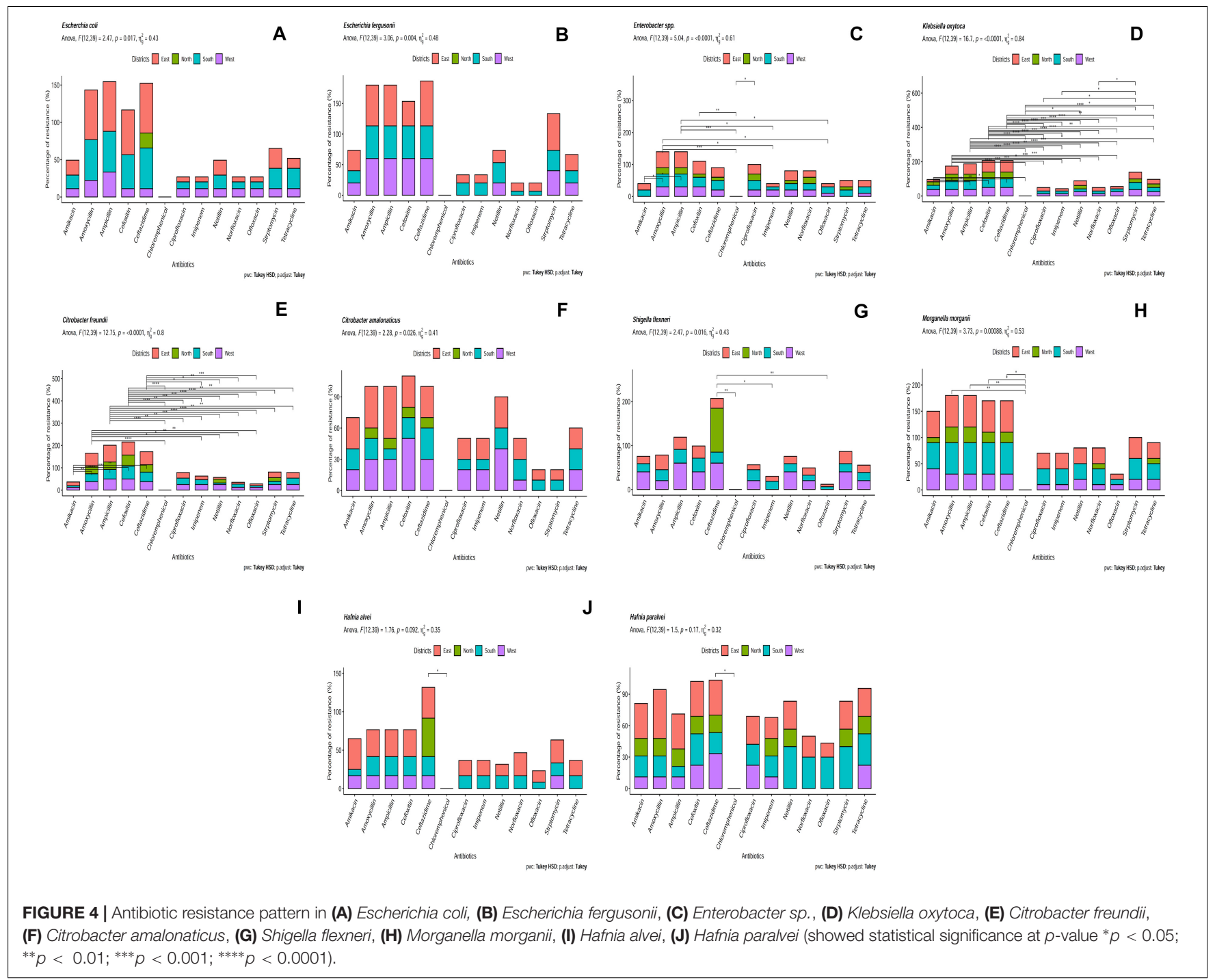

by South and West Sikkim whereas the least resistance was detected in bacterial isolates from North Sikkim. Several MDR strains were also detected. Citrobacter amalonaticus, which showed resistance to ampicillin (50\%), cefoxitin (50\%), netillin (40\%), amoxicillin (40\%). Enterobacter sp. showed resistance to ampicillin (50\%), amoxicillin (50\%), and cefoxitin (40\%). Morganella morganii showed resistance to ampicillin, amoxicillin, cefoxitin, and ceftazidime with each accounting for $60 \%$ (Figure 4). Hafnia alvei isolates showed resistance to ceftazidime (50\%), amikacin (40\%), ampicillin (35\%), amoxicillin (35\%), and cefoxitin (35\%) (Figure 4). However, all isolates showed $0 \%$ resistance to chloramphenicol (Figure 4). Shigella flexneri, E. coli and Hafnia alvei isolates from the North Sikkim showed resistance to ceftazidime only $(100,20$, 50\%) (Figure 4).

\section{Multiple Antibiotic Resistance Index}

Multiple antibiotic resistance (MAR) indexing is one the easiest method for making distinction in antibiotic resistance pattern among different isolates and for making health risk assessment. It indicates whether the identified isolates are from a region of high or low antibiotic use. The MAR index value greater than 0.2 indicates higher risk of source contamination where antibiotics are most often used (Davis and Brown, 2016). MAR value equals to 1 indicates $100 \%$ resistance of the isolate to the tested antibiotics and the source is at higher risk due to frequent use of antibiotics. East and South Sikkim bacterial isolates showed MAR index of 0.92 whereas the MAR index of West Sikkim isolates ranged from 0.46 to 0.92 . Isolates from North Sikkim showed the lowest MAR index $(0-0.61)$ (Figure 5A). Test of analysis of variance showed significant difference among the mean of the results, and the post hoc Tukey showed significant difference among east, west, south, and north districts data (Figure 5B).

\section{Principal Component Analysis Based on Antibiotic Resistance}

The correlation between spring water of different districts of Sikkim using antibiotic resistant isolates as an exploratory 

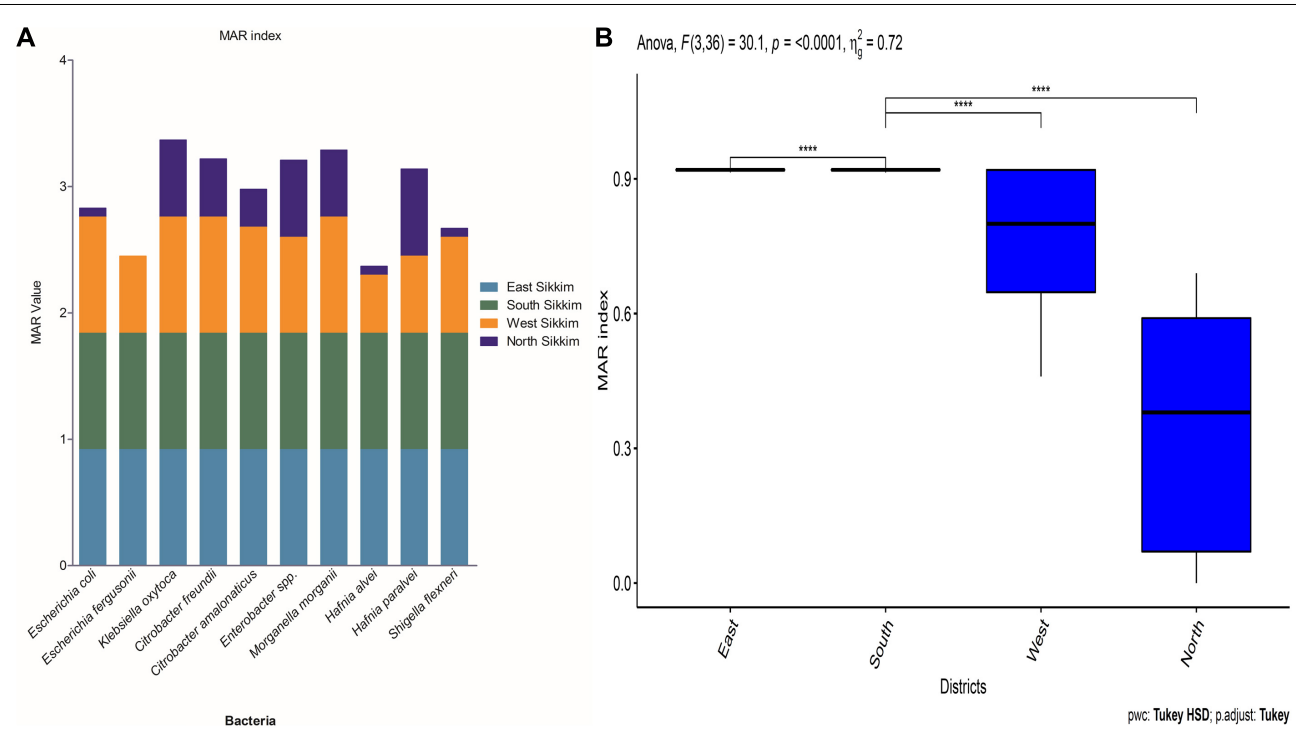

FIGURE 5 | (A) The graph showing the MAR index of bacterial species from different districts of Sikkim. (B) Statistical significance between the data of different districts (*showed statistical significance at $p$-value $\left.{ }^{* * * *} p<0.0001\right)$.

variable was carried out by principal component analysis (PCA). The F1 component (principal component 1) possessed $67.40 \%$ variability whereas F2 (principal component 2) showed $20.50 \%$ variability and together they accounted for $87.90 \%$ variability of the data. Correlation between the water samples of different districts of Sikkim was significant with a $p$-value $<0.05$. A significant positive correlation was observed between East and South Sikkim water samples. Water samples from West and North Sikkim were totally different in terms of distribution of antibiotic resistant isolates.

\section{Detection of Virulence Gene in E. coli}

Escherichia coli isolates from East Sikkim carried the lowest percentage of $\operatorname{st} x 1(73.33 \%, p<0.05)$ gene and highest percentage of elt gene $(86.66 \%, p<0.05)$. E. coli isolates from North Sikkim showed single virulence gene viz. elt $(40 \%, p<0.05)$. Isolates from West Sikkim carried highest percentage of eae $(66.66 \%$, $p<0.0004)$ gene followed by elt gene (55.55\%, $p<0.0001)$. E. coli isolates from South Sikkim showed the highest percentage of stx 1 (81.81\%, $p<0.0001)$ gene followed by elt $(72.72 \%, p<0.0001)$ and eae $(63.63 \%, p<0.0004)$ gene (Figure 6).

\section{Detection of Antibiotic Resistance Gene in E. coli Isolates of Spring Water of Sikkim}

Escherichia coli isolates from East and South Sikkim had the highest percentage of ampicillin (CITM) $(80 \%, p<0.05$, $p=0.0079)$ resistance gene followed by that of tetracycline (tetO) (66.66\%, $p<0.05, p=0.0079)$ and quinolones $(q n r B)(40 \%$, $p<0.05, p=0.0079)$. E. coli isolates from West Sikkim showed highest percentage of ampicillin $(77.77 \%, p<0.05, p=0.0034)$ resistance gene followed by that of streptomycin $(66.66, p<0.05$, $p=0.0034)$ and quinolones (44.44\%, $p<0.05, p=0.0034)$.
E. coli isolates from North Sikkim showed highest percentage of ampicillin $(60 \%, p<0.05, p=0.0032)$ and tetracycline $(60 \%$, $p<0.05, p=0.0032)$ resistance genes followed by that of streptomycin $(40 \%, p<0.05, p=0.0032)$ and quinolones $(40 \%$, $p<0.05, p=0.0032$ ) (Figure 7).

\section{Correlation Between Antibiotic Resistance and Virulence Gene}

In Pearson correlation between ARG and virulence gene of E. coli, it was found that tetracyclin resistance (tetO) gene showed positive association (0.96) with elt gene (statistically significant at $p<0.05)$ and stx1 gene (0.83) (non-significant). Whereas quinolones $(q n r B)$ resistance gene showed positive correlation (0.98) with eae gene with statistical significance $(P<0.05)$. Streptomycin resistance gene $(\operatorname{aad} A 1)$ showed negative correlation with stx $1(-0.84)$ and elt $(-0.78)$ gene whereas ampicillin resistance gene (CITM) showed positive correlation (0.78) with elt gene but statistically non significant (Figure 8).

\section{DISCUSSION}

Poor hygiene and sanitation, and the contaminated water accounts for $6.3 \%$ of global deaths and $9.1 \%$ of the total global disease burden (Pal et al., 2018). In developing countries, water contamination is very common due to lack of proper water treatment systems and has become a reason for deaths of several hundred to thousands each year (Pruss-Ustun et al., 2008; Bain et al., 2014). Contamination of water sources is a concerning issue around the world because of the increasing population, climate change and anthropoegenic activities. Water quality defines health quality of a community in a population. Identification of contaminated water sources especially in developing countries and rural areas has become a need of the moment to manage and 

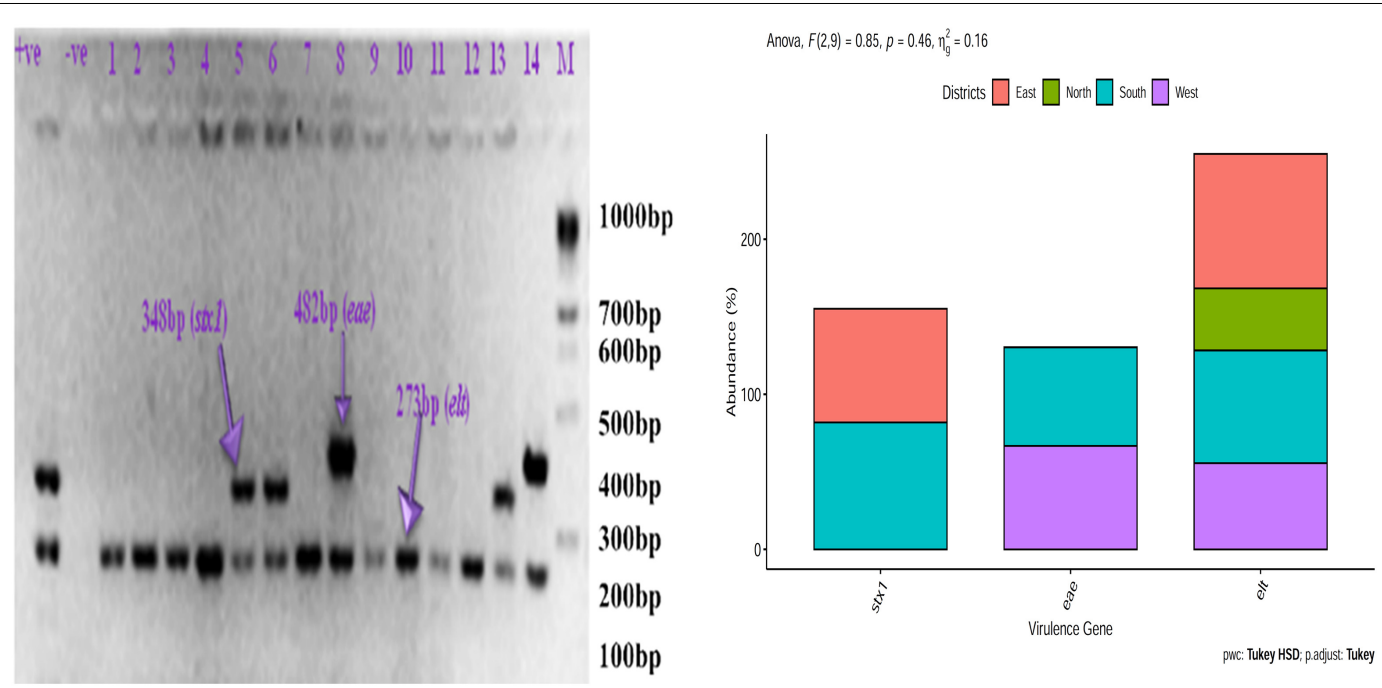

FIGURE 6 | Prevalence of virulence gene in Escherichia coli isolated from spring water of different districts of Sikkim (+ve, positive control; -ve, negative control).
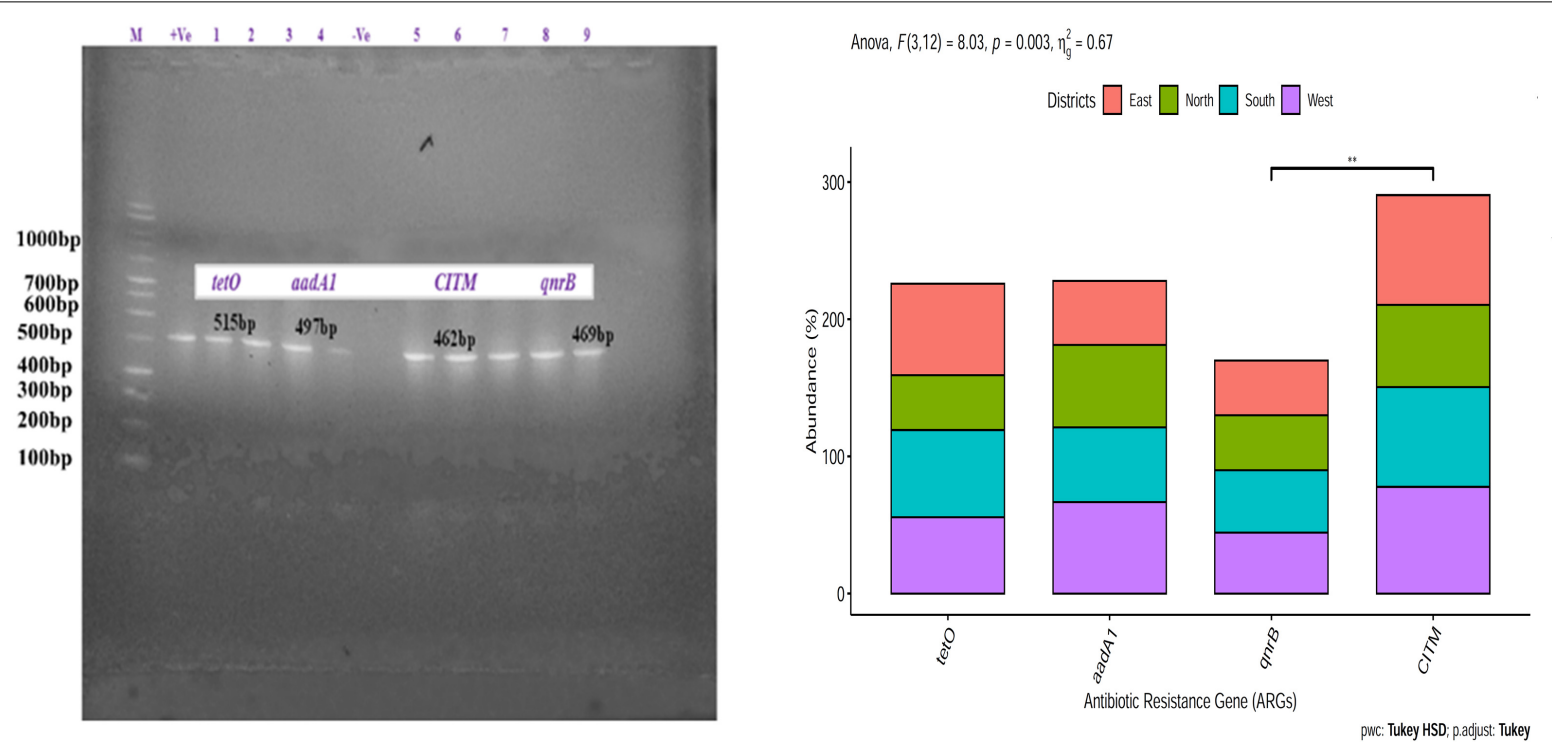

FIGURE 7 | Prevalence of antibiotic resistance gene in Escherichia coli isolates from spring water of different districts of Sikkim. *Showed statistical significance at $p$ value ${ }^{* *} p<0.01$

minimize the future health risks. In the Eastern Himalayan state Sikkim, where water sources are limited and altitude variation restricts the people to make use of mountain springs as their sole source of potable water. However, concerning question is, majority of the Sikkimese people do not use any form of filtration or pretreatment for using the spring water as a potable source. Using untreated spring water as a potable source increases the risk of transmission and getting in contact with water borne pathogens. Our previous study (Singh et al., 2019) documented how spring water and community reservoir (the place where the spring water is collected/stored prior to its supply to households) of the state can seed the future health risks owing to its alarming fecal contaminations.
Pharmaceuticals have improved the quality of life and public health, especially pharmaceutical products like antibiotics have acted as a wonder medicine that saved countless lives (Davies and Davies, 2010). However, excessive use of antibiotics in agriculture, animal husbandry, animals and humans worldwide plays a very important role in the emergence of ARB (Singh et al., 2018a; Almakki et al., 2019). Overuse of antibiotics has increased the accumulation of active antimicrobial compounds in the environment and favored the selection of ARGs and ARB (Almakki et al., 2019). Surface water remains a connecting link between the emergence and distribution of antibiotic resistance among pathogens due to direct disposal of fecal and agricultural runoff, and the hospital and municipal wastewater effluents 


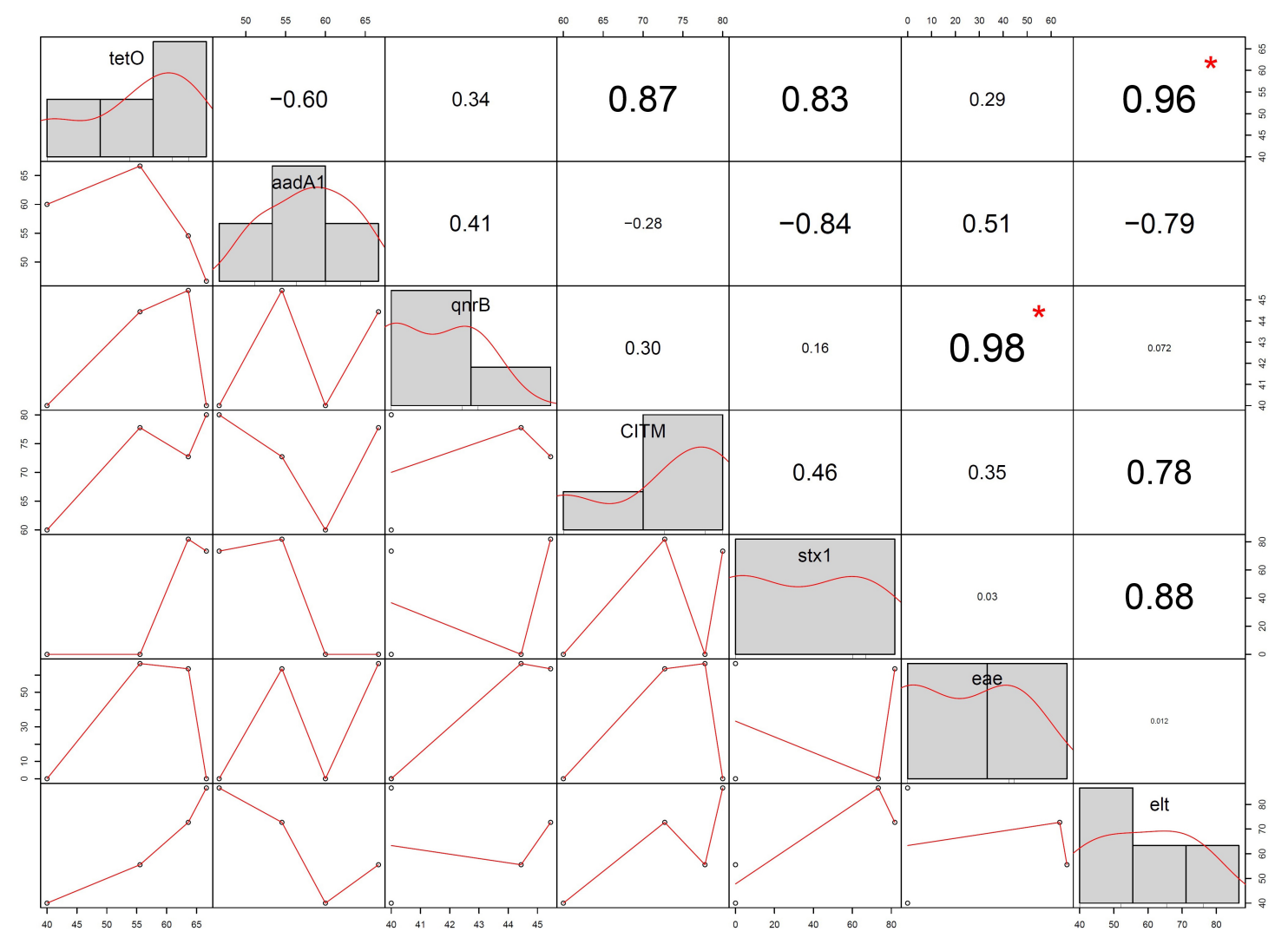

FIGURE 8 | Correlation between antibiotic resistance gene and virulence gene of Escherichia coli isolated from spring water of Sikkim (+ve, positive control; -ve, negative control; (* $=$ statistically significant).

(Grenni et al., 2018). Once the antibiotic resistance bacteria enters the waterways, they can either be consumed by humans or animals and can cause infections, or they can transfer ARGs to other bacteria which are present in that environment (Sanderson et al., 2018). In Sikkim, to maintain the continuity of water supply to the community, spring water is being collected and supplied to the community via pipelines. There have been several recent outbreaks of waterborne diseases in different areas of the state which has raised the concern about water quality. A recent report from the Ministry of Health and Family Welfare, Government of India, indicated that cholera, acute diarrheal diseases and enteric or typhoid fever is becoming a health risk in the state which needs early attention (Government of India, Ministry of Health \& Family Welfare, 2019). A total of 41816 cases of acute diarrheal disease were reported in 2017 and 41449 cases in 2018. A total of 104 cases of enteric fever were reported in 2017, and 158 cases in 2018 by the Sikkim state authorities. These numbers are alarming and our previous study also reported severe fecal contamination in the spring water of Sikkim, which needs immediate attention (Singh et al., 2019).

In this study we tried to characterize the distribution of ARB belonging to Enterobacteriaceae family and occurrence of ARGs and VGs in isolated E. coli from potable spring water sources. Characterization of Enterobacteriaceae ARBs from spring water showed a dominance of Escherichia coli, E. fergusonii, Citrobacter freundi, C. amalonaticus, Hafnia alvei, Morganella morganii, Enterobacter sp. and Shigella flexneri (Figure 2). Antibiotic susceptibility study showed that $E$. coli isolates were resistant to ceftazidime $(73.33 \%)$, ampicillin $(66.66 \%)$ and amoxicillin (66.66\%). However certain degree of resistance of the E. coli isolates was also observed against norfloxacin (6.66\%) and ofloxacin $(6.66 \%)$. E. coli isolates were also found resistant to tetracycline $(26.66 \%)$ and streptomycin (60\%) (Figure 4A). The resistance of $E$. coli to common antibiotics is becoming a serious concern for clinical facilities. Reports of multiple antibiotic-resistant E. coli isolates from water sources can be found worldwide. A study from Central Michigan had reported E. coli isolates from water samples, human septage, domestic fecal matter, and wild animal fecal matter to be resistant to tetracycline (27.30\%), cephalothin (22.70\%), sulfisoxazole (13.30\%), and streptomycin (13.10\%) (Sayah et al., 2005). Another study from Leaon, Nicaragua showed widespread resistance to Ampicillin (100\%), chloramphenicol (69\%), ciprofloxacin (69\%), and nalidixic acid (70\%) in E. coli isolated from well water, sewage water, and hospital effluents (Amaya et al., 2012). On an intriguing and contrary note E. coli isolates from spring water of Sikkim did not showed any resistance to chloramphenicol. The probable reason behind the chloramphenicol susceptibility of the isolates may be the result of infrequent consumption of chloramphenicol in the region as this antibiotic is prescribed 
for diseases like typhoid, cholera, conjunctivitis, etc. which are less prevalent in Sikkim (Singh et al., 2018c). The possible reason behind the development of resistance to the common antibiotics could be the frequent use or misuse of antibiotics due to easy availability and affordability (Shakya et al., 2013). In India, E. coli isolated from the Ganga river showed resistance to antibiotics cephalosporin (37\%), ampicillin (20\%), amoxicillin (20\%), tetracycline (20\%), and ciprofloxacin $(5.30 \%)$ (Biswas et al., 2015). Similarly, several studies had reported the presence of antibiotic-resistant E. coli in different environmental and clinical samples (Sayah et al., 2005; Ram et al., 2007, 2008; Li et al., 2010; Tagoe et al., 2011; Guo et al., 2014, 2017; Adzitey et al., 2015; Chen et al., 2017; Muringani, 2017; Amer et al., 2018; Diwan et al., 2018; Igwaran et al., 2018; Lu et al., 2018; Mishra et al., 2018; Mitali et al., 2018; Vital et al., 2018; Amador et al., 2019; Sandhu et al., 2019). Study on distribution of ARGs in the present study reflects that the spring water of Sikkim are reservoirs of multiple ARGs. Isolated E. coli from spring water of Sikkim showed the presence of tetracycline $(t e t O)$, streptomycin (aadA1), quinolones ( $q n r A)$ and ampicillin (CITM) resistance genes (Figure 7). In a similar study, E. coli isolated from river Ganga were found to have genes for neomycin (100\%), streptomycin (33.30\%), and ampicillin (6.60\%) resistance (Ram et al., 2007). Different surface water samples from Hangzhou city, China had reported tetracycline resistance gene $(89.02 \%)$ in E. coli isolates (Chen et al., 2017). The occurrence of plasmid-encoded tetracycline resistance gene among E. coli in the spring water of Sikkim may increase the possibility of horizontal gene transfer in susceptible bacteria. ARG in the E. coli isolated from foods, and clinical and environmental samples had been frequently reported in many developing countries (Ram et al., 2007, 2008; Li et al., 2010; Guo et al., 2014, 2017; Chen et al., 2017; Amer et al., 2018; Diwan et al., 2018; Sandhu et al., 2019).

Humans and animals both are colonized by different strains of $E$. coli but their colonization is asymptomatic while expression of stx, elt, or eae genes defines the pathogenesis in humans (Ram et al., 2007). E. coli isolated from spring water of Sikkim showed highest percentage of elt gene (63.73\%) followed by stx1 gene (38.78\%) and eae gene (32.57\%) (Figure 6). The presence of stx1 gene in E. coli showed the prevalence of STEC (Shiga toxinproducing E. coli) in the spring water of Sikkim and indicated animal or human origin fecal contamination of water bodies. A similar study on E. coli isolates from river Ganga and Gomati, India showed the presence of virulence genes such as stxl (82\%), stx2 (82\%), eae gene (70.60\%), and elt gene (33.30\%) (Ram et al., $2007,2008)$. Due to a very low infection dose (1-10 colonyforming unit) with short incubation period ( $3 \mathrm{~h}$ ) Shiga toxinproducing E. coli (STEC) have a very high rate of transmission and infection to humans and animals (Kuhnert et al., 2000; Ranjbar et al., 2017). Drinking water contaminated with STEC can cause diarrheal disease in humans and animals (Obi et al., 2004). Several studies reported the presence of virulence gene stx in E. coli from human stool samples, environmental samples, fermented dairy products and food samples (Kuhnert et al., 2000; Qadri et al., 2005; Ram et al., 2007, 2008; Sidhu et al., 2013; Dehkordi et al., 2014; Ranjbar et al., 2017, 2018). Expression of eae gene is essential for the complete functioning of virulence gene STEC (stx 1 and stx2) in humans. The expression of stx 1 and stx2 gene leads to hemorrhagic colitis (HC) and hemolytic uremic syndrome (HUS) (Obi et al., 2004). The strain of E. coli which bear heat-labile $(L T)$ and heat-stable $(S T)$ enterotoxin along with colonizing factor were described as ETEC strain (Gaastra and Svennerhoim, 1996), and $63.73 \%$ of E. coli isolates from the spring water of Sikkim had elt gene. Similar observations have been made in the surface water studies conducted in India, Bangladesh and South Africa (Gaastra and Svennerhoim, 1996; Kuhnert et al., 2000; Obi et al., 2004; Ram et al., 2007). Gain and loss of VGs by $E$. coli can determine the fate of pathogenesis (Ram et al., 2007). Thus, the presence of different plasmid-encoded virulence genes (elt, stxl, eae) bearing E. coli strain in the spring water of Sikkim indicates possible future health risks. Poor sanitation facility and population pressure have increased the probability of the presence of virulent gene harboring pathogenic bacteria in the surface water of developing countries.

Escherichia fergusonii (7.35\%) was reported from the spring water of Sikkim (Figure 2). Escherichia fergusonii are rarely occurring, emerging pathogens for humans and animals. It was earlier known as enteric group 10 and named after American microbiologist William H. Ferguson (Farmer et al., 1985). Escherichia fergusonii isolates from spring water of Sikkim showed resistance to different classes of antibiotics including ceftazidime (73.33\%), streptomycin (60\%), ampicillin (60\%), and cefoxitin (40\%) (Figure 4B). A similar study from Turkey found E. fergusonii isolates were resistant to penicillin G (100\%), erythromycin (76.90\%), and oxytetracycline (23\%) (Parin et al., 2018). MDR E. fergusonii was also isolated from the Orissa (Mahapatra et al., 2009).

Another major pathogenic bacterium identified from the spring water of Sikkim was Klebsiella. It is the second leading cause of nosocomial infection after E. coli among Enterobacteriaceae. Klebsiella are opportunistic pathogens that cause several diseases like pneumonia, urinary tract infection (UTI), soft tissue infection, and septicemia (Hagiwara et al., 2013). Taxonomic identification showed $9.23 \%$ of Klebsiella isolates from spring water were K. oxytoca (Figure 2). However, a patient infected with $K$. oxytoca may remain asymptomatic but it is still considered as an opportunistic pathogen associated with nosocomial infection in cohorts of hospitalized patients including neonates and children (Savino et al., 2009, 2011; Gajul et al., 2015; Singh et al., 2016). Recent studies showed that Klebsiella oxytoca is becoming an emerging threat with higher acquisition of antibiotic resistance to common antibiotics than by other major pathogens of genus Klebsiella viz., Klebsiella pneumoniae (Singh et al., 2016). K. oxytoca isolates from spring water of Sikkim showed resistance to cefoxitin (66.66\%), ceftazidime (66.66\%), ampicillin (60\%), and streptomycin (40\%) (Figure 4D). Singh et al. (2016) from India, reported K. oxytoca from different clinical samples that showed resistance to ceftriaxone (72\%), imipenem (59\%), amikacin (71\%), gentamicin (71\%), ciprofloxacin (81\%), and piperacillin/tazobactam (75\%). K. oxytoca isolated from urine samples of UTI infected Turkish children showed resistance to ampicillin (97\%), cephalothin (48.40\%), cefuroxime (36.40\%), amoxicillin (18.20\%), and ceftriaxone (7.10\%) (Gunduz and Uludað Altun, 2018). 
Citrobacter spp. are commensal bacteria present in intestinal tracts of humans and several animals (Liu et al., 2017). Citrobacter spp. has been also isolated from water, soil and sewage (Lee et al., 2010; Liu et al., 2017). C. freundii (9.48\%) and C. amalonaticus (10.95\%) were the two major species isolated from the spring water of Sikkim (Figure 2). AST of C. freundii showed its resistance to ampicillin (75\%), amoxicillin (58.33\%), cefoxitin (58.33\%), tetracycline (25\%), and streptomycin (25\%). Whereas C. amalonaticus showed resistance to ampicillin (50\%), cefoxitin (50\%), amoxicillin (40\%), and netillin (40\%) (Figures 4E,F). Commensal C. freundii isolated from the stool samples of children aged 3-14 years showed resistance to ampicillin (100\%), Co-trimoxazole (100\%), cefotaxime (100\%), amoxiclav $(100 \%)$, ciprofloxacin $(100 \%)$, and imipenem $(100 \%)$ whereas no resistance was reported against gentamicin and amikacin (Sandhu et al., 2019). C. freundii isolated from different clinical samples such as urine, stool, blood, and pus from India showed resistance to norfloxacin (79.59\%), ciprofloxacin (71.53\%), ceftazidime (69.39\%), cefotaxime (67.35\%), and meropenem (4.08\%) (Khanna et al., 2012).

Enterobacter is a genus of Gram-negative, rod-shaped, facultative anaerobe, non-spore forming bacteria belonging to family Enterobacteriaceae. They are associated with bacteremia, septic arthritis, endocarditis, urinary tract infection, respiratory tract infection, intra-abdominal infection, skin and soft tissue infection (Singh et al., 2018c). Enterobacter spp. isolated from the spring water of Sikkim (Figure 2) showed resistance to ampicillin (50\%), cefoxitin (40\%), netillin (30\%), ciprofloxacin $(30 \%)$, tetracycline $(30 \%)$, and imipenem $(10 \%)$ (Figure 4C). Enterobacter spp. isolated from pharmaceuticals wastewater of Southwestern Nigeria showed resistance to ampicillin (100\%), amoxicillin (100\%), chloramphenicol (100\%), sulfonamide (100\%), trimethoprim (98\%), and streptomycin (92\%) (Obayiuwana et al., 2018). However, Enterobacter spp. isolates from the spring water of Sikkim did not show any resistance to chloramphenicol. The majority of the studies, has indicated the widespread multidrug resistance in Enterobacter spp. isolates against ampicillin, cephalothin, cefoxitin, septrin, chloramphenicol, amoxicillin, streptomycin, and ciprofloxacin (Bolaji et al., 2011; Jabbar Ibrahim and Kareem Hameed, 2015). In the United States, Enterobacter spp. isolates are the second most commonly encountered carbapenem resistant Enterobacteriaceae members which had progressively contributed to the spread of the carbapenem-resistant infection (Annavajhala et al., 2019). Multi-drug resistant Enterobacter spp. (13.44\%) were isolated from the Cauvery river, India, in which about $93.85 \%$ isolates showed full resistance to all the 32 antibiotics used in that study (Skariyachan et al., 2015)

Morganella is a genus of Gram-negative, rod-shaped, facultative anaerobic bacteria, first isolated from pediatric fecal culture by Morgan et al. (1906). This bacterium is normally found in the environment and intestinal tract of mammals as a part of normal flora (Liu et al., 2016). Morganella morganii acts as opportunistic pathogen which causes sepsis, abscess, bacteremia, and UTI (Hawkey et al., 1983; Liu et al., 2016; Simkhada et al., 2016; Ibrahim et al., 2017; Guo et al., 2019;
Minnullina et al., 2019). Isolates of Morganella morganii (10.95\%) from spring water of Sikkim (Figure 2) showed resistance to ampicillin (60\%), cefoxitin (60\%), amikacin (50\%), streptomycin (40\%), and tetracycline (30\%) (Figure $4 \mathbf{H}$ ). Morganella morganii is reported from many UTI patients (Liu et al., 2016; Hawkey et al., 2018; Minnullina et al., 2019). Morganella morganii isolated from various hospital samples in China showed resistance to tetracycline, amikacin, gentamicin, ceftazidime, cefepime, imipenem, meropenem (Guo et al., 2019). Guo et al first time reported the NDM-5 producing Morganella morganii (Guo et al., 2019). From a tertiary care hospital of Nepal (a Himalayan country), Morganella morganii showed resistance to chloramphenicol (100\%), cefixime (100\%), cefotaxime (100\%), gentamicin (100\%), amikacin (100\%), and imipenem (100\%) (Simkhada et al., 2016). However, Morganella morganii isolates from Sikkim did not show any resistance to chloramphenicol. Multidrug resistant Morganella morganii (5.59\%) was reported from Nigerian hospital wastes (Mustapha and Imir, 2019). Cephalosporin (0.50\%) and ciprofloxacin $(0.50 \%)$ resistant Morganella morganii were reported from a healthy community of Chandigarh, India $(0.50 \%)$ (Monica et al., 2018).

Hafnia alvei (8.10\%) and $H$. paralvei (9.68\%) were identified from the spring water of Sikkim (Figure 2). Hafnia alvei showed resistance to ceftazidime (40\%), amikacin (40\%), ampicillin (35\%), and cefoxitin (35\%) and Hafnia paralvie were found resistant to amoxicillin (46.66\%), streptomycin (40\%), netillin (40\%), and cefoxitin (33.33\%) (Figures $4 \mathbf{I}, \mathbf{J}$ ). Hafnia alvei is a Gram-negative, rod-shaped, gastrointestinal commensal bacteria belonging to family Enterobacteriaceae and is an opportunistic pathogen. They cause nosocomial infection, bacteremia, peritonitis, UTI, and pneumonia (Janda and Abbott, 2006; Lancelevee et al., 2014; Loya and Walsh, 2015; Litrenta and Oetgen, 2017; Baral et al., 2018). In a study from Nepal, Hafnia alvei was isolated and identified from an 11 months old child who suffered from bacteremia following bronchopneumonia (Baral et al., 2018). From different clinical samples of India, such as urine, wounds, blood, cerebrospinal fluid (CSF), etc. extensively resistant and pan drug-resistant $H$. alvei had been reported (Bhatt et al., 2015).

Shigella a genus of Gram-negative, rod-shaped, enteroinvasive bacteria causes shigellosis which is responsible for significant mortality and morbidity in young children and immunocompromised adults (Ranganathan et al., 2019). In the developing world $S$. flexneri, while in the more-industrialized regions Shigella sonnei, are responsible for the majority of disease burden (Kahsay and Muthupandian, 2016). Shigellosis is a global human health problem that kills about 700,000 peoples each year worldwide of which most belong to the age group of below 5 years (DuPont et al., 1989). Shigella flexneri was the dominant species identified from the spring water of Sikkim (Figure 2). East Sikkim (12.41\%) being the hub of industrial development of the state counted the highest number of Shigella flexneri followed by South (10\%) and North Sikkim (1.82\%). Shigella flexneri isolates showed resistance to ceftazidime (60\%), cefoxitin (40\%), streptomycin (40\%), netillin (40\%), amikacin (40\%), and ofloxacin (5.50\%). S. flexneri isolates 
from North Sikkim showed resistance to only ceftazidime (100\%) (Figure 4G). Similar antibiotic resistance profile can be found in the Shigella flexneri $(71.1 \%)$ isolates from Shanxi Province, China. Isolates were resistant to ampicillin (98.50\%), ticarcillin (95\%), trimethoprim/sulfamethoxazole (85.20\%), and chloramphenicol (78.60\%) (Wang et al., 2019). In another study, Shigella flexneri $(21 \%)$ isolates from Iran were found to show resistance to cotrimoxazole (100\%), ampicillin (100\%), tetracycline $(75 \%)$, chloramphenicol (50\%), cefixime (50\%), and ampicillin (33.30\%) (Abbasi et al., 2019). A study from Kerala, India reported Shigella flexneri isolates to display resistance to nalidixic acid (88.80\%), ampicillin (83.30\%), cotrimoxazole (83.30\%), ciprofloxacin (77.70\%), and furazolidone $(38.80 \%)$ (Madhavan et al., 2018). The Oceanic region of Australia had also reported ampicillin (77\%), tetracycline (74\%), chloramphenicol (60\%), and sulfamethoxazole/trimethoprim (49\%) resistant Shigella flexneri (Malau et al., 2018). The children from Southern Mozambique had been recently shown to carry Shigella flexneri (70.1\%) which were resistant to sulfamethoxazole/trimethoprim $(62.70 \%)$, tetracycline (49.30\%), ampicillin (46.30\%), and chloramphenicol (44.80\%) (Vubil et al., 2018). However, no chloramphenicol resistance was observed by us in the isolates from Sikkim.

Though a large number of antibiotics were used in the current study to detect the prevalent antibiotics resistance pattern, our study was limited by the use of bacteria belonging to Enterobacteriaceae family for assessing the spread of antibiotics resistance. So, there exists a chance that more resistant bacteria from different families might have been missed out, and the estimated antibiotics resistance rate might be an underestimation of the problem. However, lack of any water quality studies especially on antibiotic resistance pattern and distribution of antibiotic resistant pathogen makes it unique and it provides a baseline for future water quality research. This study suggested that spring water of Sikkim have high antibiotic resistance bacteria and ARG. Several risk factors such as direct antibiotic application, antibiotic resistance feed as well as environmental factors may have played vital role in distribution of antibiotic resistance in this ecosystem. More studies are needed to reveal a broad picture of antibiotic resistance in spring water of Sikkim and to set standard protocols or policies for proper treatment and management of spring water. Springs are free flowing ground water which flows in the form of surface water. So, there might be chances of contamination either at source, during free-flowing or during distribution of the water up to the household level. Some of the basic ground level management protocols which can be helpful in maintaining the water quality are:

(1) Springs should be protected from unnecessary anthropogenic/human disturbances.

(2) Frequent cleaning of the community water tanks and supply system using standard protocols.

(3) Prevent mixing of runoff water during rainy season to spring water, which carries large number of waste material including fecal from animal and household discharges.

(4) Proper chlorination of water source before supplying to the household.
(5) Water samples must be tested for both physicochemical and microbiological quality at frequent intervals (e.g., monthly, quarterly). Before supplying to the households, quality indicator/parameters should be checked and compared with standard guidelines of BSI and WHO.

(6) Putting fences around the springs to prevent direct access to animals as well as humans.

(7) Periodical inspection for the presence of indicator organism (fecal coliforms) in the spring water before supply (e.g., monthly, quarterly).

(8) Prevent disposal of any kind of waste material near the spring water sources.

(9) At household level, proper boiling or filtration before consumption is recommended.

The community needs to be educated about general hygiene, different methods available for household-level water treatment, and the importance of clean water for children and their health to avoid impending health disaster associated with the unsafe water supply.

\section{CONCLUSION}

Antibiotic resistance has become a major challenge worldwide, especially in developing countries like India. Easy accessibility of antibiotics, self-prescription, incomplete treatment course of antibiotics combined with poor management of waste disposal, poor water quality and hygiene contribute to rapid distribution and occurrence of antibiotic resistance in pathogenic and environmental bacteria. The present study showed there is a high incidence rate of multiple antibiotic resistant enteric bacteria in the spring water of Sikkim and suggests spring water are not suitable for drinking without prior treatment or filtration. The Sikkimese community may be at greater risk of contracting infection due to extensive use of spring water for drinking, cooking and other household purposes. The high rate of antibiotic resistance occurrence among environmental bacteria could be a result of indiscriminate use of antibiotics in human, animal and agricultural sectors. The presence of MDR enteric Gram-negative bacteria in the spring water of Sikkim warrants an instant commitment to the rational use of antibiotics as much as possible. The study indicates the emerging imminent threat from antibiotic-resistant pathogens in the area and mandates for immediate remedial measures including educating the community about proper sanitation, hand hygiene, and drinking water treatment practices to successfully contain the impact on the community. The extent of the problem of this emergence of antibiotic resistance can be managed by conducting antibiotic surveillance program, sensible use of antibiotics, use of the alternative bio-control agents, creating awareness in public about the rational use of antibiotics, and intensive effort between students, doctors, research scientist, industrial participants and policymakers. This study also warrants further examination of spring water samples from surrounding area of South East Asia that share similar geography and have similar livelihood practices to plan a comprehensive approach for the containment of the emerging health problem in the region. 


\section{DEDICATION NOTE FROM SAMER SINGH}

This paper is dedicated to the fond memory of Dr. Hare Krishna Tiwari - a great friend, colleague, and collaborator. His sudden passing away on 27th September 2020, when this article was in production, deeply stunned and saddened us and so many other colleagues alike in the field. His scholarly pursuit, perseverance, and dedication to the field as well as the mentoring and career counseling of scholars will be passionately remembered. This article will bring back the fond memories of what a pleasure it was to be his friend, colleague, and collaborator. I hope this note bears testimony to the honor placed on his dedication, scholarly contribution, and leadership in the field. Dr. Hare Krishna Tiwari was corresponding author of the paper upto the day of its acceptance. Placing of his name, not as a corresponding author in the final version is purely for technical reasons.

\section{DATA AVAILABILITY STATEMENT}

The datasets presented in this study can be found in online repositories. The names of the repository/repositories and accession number(s) can be found in the article/ Supplementary Material.

\section{AUTHOR CONTRIBUTIONS}

HT designed the study, supervised the study, and helped in manuscript preparation. AS performed the experiments, analyzed the data, and prepared the manuscript. SD and SS analyzed the data and prepared the manuscript. VG helped in the sample collection, survey, and lab experiments. SK and IN

\section{REFERENCES}

Abbasi, E., Abtahi, H., Belkum, A., Van, and Ghaznavi-Rad, E. (2019). Multidrugresistant Shigella infection in pediatric patients with diarrhea from central Iran. Infect. Drug Resist. 12, 1535-1544.

Adegoke, A. A., Madu, C. E., Aiyegoro, O. A., Stenström, T. A., and Okoh, A. I. (2020). Antibiogram and beta-lactamase genes among cefotaxime resistant E. coli from wastewater treatment plant. Antimicr. Resist. Infect. Contr. 9, 1-12. doi: 10.1186/s13756-020-0702-4

Adzitey, F. (2020). Incidence and antimicrobial susceptibility of Escherichia coli isolated from beef (meat muscle, liver and kidney) samples in Wa Abattoir, Ghana. Cogent Food Agricult. 6:1718269. doi: 10.1080/23311932.2020.171 8269

Adzitey, F., Nafisah, S., and Haruna, A. (2015). Antibiotic Susceptibility of Escherichia coli Isolated from some Drinking Water Sources in Tamale Metropolis of Ghana. Curr. Res. Bacteriol. 8, 34-40. doi: 10.3923/crb.2015.34.40

Al-Bahry, S., Al-Sharji, N., Yaish, M., Al-Musharafi, S., and Mahmoud, I. (2016). Diversity of Tetracycline Resistant Genes in from Human and Environmental Sources. Open Biotechnol. J. 10, 289-300. doi: 10.2174/1874070701610010289

Almakki, A., Jumas-Bilak, E., Marchandin, H., and Licznar-Fajardo, P. (2019). Antibiotic resistance in urban runoff. Sci. Total Environ. 667, 64-76. doi: 10. 1016/j.scitotenv.2019.02.183

Amador, P., Fernandes, R., Prudêncio, C., and Duarte, I. (2019). Prevalence of Antibiotic Resistance Genes in Multidrug-Resistant Enterobacteriaceae on Portuguese Livestock Manure. Antibiotics 8:23. doi: 10.3390/antibiotics8010023 helped in manuscript preparation. YL helped in the selection of study area and official documentation regarding the study. All the authors contributed to the article and approved the submitted version.

\section{ACKNOWLEDGMENTS}

We wish to thank the State Institute of Rural Department, Government of Sikkim for its helping hand in providing information about springs locations and water sample collection. We would also like to thank all the faculty member, non-teaching staff of the Department of Microbiology, Sikkim University for their continuous support and help throughout the study.

\section{SUPPLEMENTARY MATERIAL}

The Supplementary Material for this article can be found online at: https://www.frontiersin.org/articles/10.3389/fmicb. 2020.581072/full\#supplementary-material

Supplementary File 1| Springs Detail.

Supplementary File 2 | Flow chart of the study design.

Supplementary File $\mathbf{3}$ | Colony and cell morphology of bacterial isolates on different culture media.

Supplementary File $\mathbf{4}$ | Standard biochemical test used for the identification of bacterial isolates.

Supplementary File $\mathbf{5}$ | 16 S rRNA gene sequencing result and accession number.

Supplementary File 6 | Antibiotic resistance pattern of bacterial isolates of spring water of Sikkim (in percentage).

Amaya, E., Reyes, D., Paniagua, M., Calderón, S., Rashid, M. U., Colque, P., et al. (2012). Antibiotic resistance patterns of Escherichia coli isolates from different aquatic environmental sources in León, Nicaragua. Clin. Microbiol. Infecti. 18, E347-54. doi: 10.1111/j.1469-0691.2012.03930.x

Amer, M. M., Mekky, H. M., Amer, A. M., and Fedawy, H. S. (2018). Antimicrobial resistance genes in pathogenic Escherichia coli isolated from diseased broiler chickens in Egypt and their relationship with the phenotypic resistance characteristics. Veter. World 11, 1082-1088. doi: 10.14202/vetworld.2018.10821088

American Public Health Association (1999). "Detection of pathogenic bacteria, standard methods for the examination of water and wastewater," in American Water Works Association and the Water Environment Federation 20th ed, eds E. W. Rice, R. B. Baird, A. D. Eaton, and L. S. Clesceri, (Washington, DC: American Public Health Association).

Anand, T., Bera, B. C., Vaid, R. K., Barua, S., Riyesh, T., Virmani, N., et al. (2016). Abundance of antibiotic resistance genes in environmental bacteriophages. J. Gener. Virol. 97, 3458-3466. doi: 10.1099/jgv.0.000639

Annavajhala, M. K., Gomez-Simmonds, A., and Uhlemann, A. C. (2019). Multidrug-resistant Enterobacter cloacae complex emerging as a global, diversifying threat. Front. Microbiol. 10:1-8. doi: 10.3389/fmicb.2019.00044

Bain, R., Cronk, R., Hossain, R., Bonjour, S., Onda, K., Wright, J., et al. (2014). Global assessment of exposure to faecal contamination through drinking water based on a systematic review. Trop. Med. Int. Health 19, 917-927. doi: 10.1111/ tmi. 12334

Bandyopadhyay, S., Lodh, C., Rahaman, H., Bhattacharya, D., Bera, A. K., Ahmed, F. A., et al. (2012). Characterization of shiga toxin producing (STEC) and 
enteropathogenic Escherichia coli (EPEC) in raw yak (Poephagus grunniens) milk and milk products. Res. Veter. Sci. 93, 604-610. doi: 10.1016/j.rvsc.2011. 12.011

Baquero, F., Martínez, J. L., and Cantón, R. (2008). Antibiotics and antibiotic resistance in water environments. Curr. Opin. Biotechnol. 19, 260-265. doi: 10.1016/j.copbio.2008.05.006

Baral, N., Nayak, N., Shrestha, R., Parajuli, R., Hamal, D., Bhatta, D. R., et al. (2018). Hafnia Alvei Bacteremia Following Bronchopneumonia in an Eleven Month Old Child: a Case Report From a Tertiary Care Hospital in Nepal. Int. J. Adv. Life Sci. Res. 1, 22-25. doi: 10.31632/ijalsr.2018v01i02.004

Bengtsson-Palme, J., Kristiansson, E., and Larsson, D. G. J. (2018). Environmental factors influencing the development and spread of antibiotic resistance. FEMS Microbiol. Rev. 42, 68-80. doi: 10.1093/femsre/fux053

Bhatt, P., Tandel, K., Shete, V., and Rathi, K. R. (2015). Burden of extensively drug-resistant and pandrug-resistant Gram-negative bacteria at a tertiarycare centre. $N$ Microb. $N$ Infect. 8, 166-170. doi: 10.1016/j.nmni.2015. 01.003

Biswas, K., Paul, D., and Sinha, N. (2015). Prevalence of Multiple AntibioticResistant Coliform Bacteria in the Water of River Ganga. Front. Environ. Microbiol. 1, 44-46. doi: 10.11648/j.fem.20150103.12

Bolaji, A. S., Akande, I. O., Iromini, F. A., Adewoye, S. O., and Opasola, A. O. (2011). Antibiotic resistance pattern of bacteria spp isolated from hospital waste water in Ede South Western, Nigeria. Eur. J. Exper. Biol. 1, 66-71.

Bueno, I., Williams-Nguyen, J., Hwang, H., Sargeant, J. M., Nault, A. J., and Singer, R. S. (2018). Systematic Review: Impact of point sources on antibioticresistant bacteria in the natural environment. Zoon. Publ. Health 65, 162-184e. doi: $10.1111 /$ zph.12426

Chen, Z., Yu, D., He, S., Ye, H., Zhang, L., Wen, Y., et al. (2017). Prevalence of antibiotic-resistant Escherichia coli in drinking water sources in Hangzhou City. Front. Microbiol. 8, 1-11. doi: 10.3389/fmicb.2017.01133

CLSI (2014). M100-S25 Performance Standards for Antimicrobial Susceptibility Testing; Twenty-Fourth International Supplement, 24th Edn. Wayne, PA: Clinical and Laboratory Standards Institute.

Costa, E. C., and Arpini, C. M. (2016). Antibiotic Sensitivity Profile of Enteric Bacteria Isolated from Beach Waters and Sewage from the Municipality of Vila Velha-ES, Brazil. J. Bacteriol. Parasitol. 7, 3-7. doi: 10.4172/2155-9597.100 0280

Davies, J., and Davies, D. (2010). Origins and Evolution of Antibiotic Resistance. Microbiol. Mole. Biol. Rev. 74, 417-433. doi: 10.1128/mmbr.00016-10

Davis, R., and Brown, P. D. (2016). Multiple antibiotic resistance index, fitness and virulence potential in respiratory Pseudomonas aeruginosa from Jamaica. J. Med. Microbiol. 65, 261-271. doi: 10.1099/jmm.0.000229

Dehkordi, F. S., Yazdani, F., Mozafari, J., and Valizadeh, Y. (2014). Virulence factors, serogroups and antimicrobial resistance properties of Escherichia coli strains in fermented dairy products. BMC Res. Notes 7, 1-8. doi: 10.1186/17560500-7-217

Diwan, V., Hanna, N., Purohit, M., Chandran, S., Riggi, E., Parashar, V., et al. (2018). Seasonal variations in water-quality, antibiotic residues, resistant bacteria and antibiotic resistance genes of Escherichia coli isolates from water and sediments of the Kshipra River in Central India. Int. J. Environ. Res. Publ. Health 15, 1-16. doi: 10.3390/ijerph15061281

DuPont, H. L., Levine, M. M., Hornick, R. B., and Formal, S. B. (1989). Inoculum Size in Shigellosis and Implications for Expected Mode of Transmission. J. Infect. Dis. 159, 1126-1128.

Farmer, J. J., Fanning, G. R., Davis, B. R., Hara, C. M. O., Riddle, C., Asbury, M. A., et al. (1985). Escherichia fergusonii and Enterobacter taylorae, Two New Species of Enterobacteriaceae Isolated from Clinical Specimens. J. Clin. Microbiol. 21, $77-81$.

Gaastra, W., and Svennerhoim, A.-M. (1996). Colonization factors of Eschericbia coli (ETEC). Trends Microbiol. 4, 444-452.

Gajul, S. V., Mohite, S. T., Mangalgi, S. S., Wavare, S. M., and Kakade, S. V. (2015). Klebsiella Pneumoniae in Septicemic Neonates with Special Reference to Extended Spectrum $\beta$-lactamase, AmpC, Metallo $\beta$-lactamase Production and Multiple Drug Resistance in Tertiary Care Hospital. J. Labor. Physic. 7, 32-37. doi: 10.4103/0974-2727.151689

Government of India, Ministry of Health \& Family Welfare (2019). National Health Profile (14th Issue): Prepared by Central Bureau of Health Intelligence. Directorate General of Health Services Ministry of Health \& Family
Welfare, Government of India. Available online at: https://www.cbhidghs.nic. in/showfile.php?lid=1147

Grenni, P., Ancona, V., and Barra Caracciolo, A. (2018). Ecological effects of antibiotics on natural ecosystems: A review. Microchem. J. 136, 25-39. doi: 10.1016/j.microc.2017.02.006

Gunduz, S., and Uludað Altun, H. (2018). Antibiotic resistance patterns of urinary tract pathogens in Turkish children. Glob. Health Res. Policy 3, 1-5. doi: 10. 1186/s41256-018-0063-1

Guo, J., Li, J., Chen, H., Bond, P. L., and Yuan, Z. (2017). Metagenomic analysis reveals wastewater treatment plants as hotspots of antibiotic resistance genes and mobile genetic elements. Water Res. 123, 468-478. doi: 10.1016/j.watres. 2017.07.002

Guo, X., Li, J., Yang, F., Yang, J., and Yin, D. (2014). Science of the Total Environment Prevalence of sulfonamide and tetracycline resistance genes in drinking water treatment plants in the Yangtze River Delta, China. Sci. Total Environ. 493, 626-631. doi: 10.1016/j.scitotenv.2014.06.035

Guo, X., Rao, Y., Guo, L., Xu, H., Lv, T., Yu, X., et al. (2019). Detection and Genomic Characterization of a Morganella morganii Isolate From China That Produces NDM-5. Front. Microbiol. 10:1-9. doi: 10.3389/fmicb.2019.01156

Hagiwara, S., Murata, M., Aoki, M., Kaneko, M., and Oshima, K. (2013). Septic shock caused by Klebsiella oxytoca: An autopsy case and a survival case with driving Extracorporeal Membrane Oxygenation. Hippokratia 17, 171-173.

Haseena, M., Malik, M. F., Javed, A., Arshad, S., Asif, N., SharonZulfiqar, et al. (2017). Water pollution and human health. Environ. Risk Assess. Remed. 1, 16-19.

Hassan Rashid, M. A. U., Manzoor, M. M., and Mukhtar, S. (2018). Urbanization and its effects on water resources: An exploratory analysis. Asian J. Water Environ. Pollut. 15, 67-74. doi: 10.3233/AJW-180007

Hawkey, E. W. W. P. M., Penner, J. L., Senior, B. W., and Barton, L. J. (1983). Serious nosocomial infection caused by Morganella morganii and Proteus mirabilis in a cardiac surgery unit. J. Clin. Microbiol. 18, 5-9.

Hawkey, P. M., Warren, R. E., Livermore, D. M., McNulty, C. A. M., Enoch, D. A., Otter, J. A., et al. (2018). Treatment of infections caused by multidrugresistant gram-negative bacteria: Report of the British society for antimicrobial chemotherapy/healthcare infection society/british infection association joint working party. J. Antimicrob. Chemother. 73, iii2-iii78. doi: 10.1093/jac/ dky027

Hemmatinezhad, B., Khamesipour, F., Mohammadi, M., Dehkordi, F. S., and Mashak, Z. (2015). Microbiological Investigation of O-Serogroups, Virulence Factors and Antimicrobial Resistance Properties of Shiga Toxin-Producing Escherichia Coli Isolated from Ostrich, Turkey and Quail Meats. J. Food Safe. 35, 491-500. doi: 10.1111/jfs.12199

Hemme, C. L., Tu, Q., Shi, Z., Qin, Y., Gao, W., Deng, Y., et al. (2015). Comparative metagenomics reveals impact of contaminants on groundwater microbiomes. Front. Microbiol. 6:1-12. doi: 10.3389/fmicb.2015.01205

Ibrahim, H. K., Almayah, A. A., and Issa, A. H. (2017). Molecular Detection of Environmental Morganella morganii as Histamine Producing Bacteria Molecular Detection of Environmental Morganella morganii as Histamine Producing Bacteria. Donnish J. Med. Medic. Sci. 4, 8-13.

Igwaran, A., Iweriebor, B. C., and Okoh, A. I. (2018). Molecular characterization and antimicrobial resistance pattern of Escherichia coli recovered from wastewater treatment plants in Eastern Cape South Africa. Int. J. Environ. Res. Publ. Health 15:1237. doi: 10.3390/ijerph15061237

Jabbar Ibrahim, I. A., and Kareem Hameed, T. A. (2015). Isolation, Characterization and Antimicrobial Resistance Patterns of Lactose-Fermenter Enterobacteriaceae Isolates from Clinical and Environmental Samples. Open J. Med. Microbiol. 05, 169-176. doi: 10.4236/ojmm.2015.54021

Janda, J. M., and Abbott, S. L. (2006). The genus Hafnia: From soup to nuts. Clin. Microbiol. Rev. 19, 12-28. doi: 10.1128/CMR.19.1.12-28.2006

Kahsay, A. G., and Muthupandian, S. (2016). A review on Sero diversity and antimicrobial resistance patterns of Shigella species in Africa, Asia and South America, 2001-2014. BMC Res. Notes 9:422.

Karkman, A., Do, T. T., Walsh, F., and Virta, M. P. J. (2018). Antibiotic-Resistance Genes in Waste Water. Trends Microbiol. 26, 220-228. doi: 10.1016/j.tim.2017. 09.005

Khanna, A., Singh, N., Aggarwal, A., and Khanna, M. (2012). The antibiotic resistance pattern in citrobacter species: An emerging nosocomial pathogen in a tertiary care hospital. J. Clin. Diagn. Res. 6, 642-644. 
Krumperman, P. H. (1983). Multiple Antibiotic Resistance Indexing of Escherichia coli to Identify High-Risk Sources of Fecal Contamination of Foodst. Appl. Environ. Microbiol. 46:6.

Kuhnert, P., Boerlin, P., and Frey, J. (2000). Target genes for virulence assessment of Escherichia coli isolates from water, food and the environment. FEMS Microbiol. Rev. 24, 107-117.

Lancelevee, J., Bret, L., David, K., and Di Martino, P. (2014). Antibiotic Resistance and Adherence Properties of Hafnia alvei Clinical Isolates: A 19-Month Study in the Hospital of Orléans, France. J. Chemother. 19, 677-681. doi: 10.1179/joc. 2007.19.6.677

Lee, J. J., Sun, H. I., Park, K. S., Lee, J. E., Ahn, J. H., and Lee, S. H. (2010). Novel Variants of the qnrB Gene, qnrB22 and qnrB23,in Citrobacter werkmanii and Citrobacter freundii. Antimicr. Agents Chemother. 54, 3068-3069. doi: 10.1128/ AAC.01339-09

Li, D., Yu, T., Zhang, Y., Yang, M., Li, Z., Liu, M., et al. (2010). Antibiotic resistance characteristics of environmental bacteria from an oxytetracycline production wastewater treatment plant and the receiving river. Appl. Environ. Microbiol. 76, 3444-3451. doi: 10.1128/AEM.02964-09

Litrenta, J., and Oetgen, M. (2017). Hafnia alvei: A new pathogen in open fractures. Trauma Case Rep. 8, 41-45. doi: 10.1016/j.tcr.2017.01.019

Liu, H., Zhu, J., Hu, Q., and Rao, X. (2016). Morganella morganii, a non-negligent opportunistic pathogen. Int. J. Infect. Dis. 50, 10-17. doi: 10.1016/j.ijid.2016.07. 006

Liu, L., Lan, R., Liu, L., Wang, Y., Zhang, Y., Wang, Y., et al. (2017). Antimicrobial resistance and cytotoxicity of Citrobacter spp. in Maanshan Anhui Province, China. Front. Microbiol. 8, 1-12. doi: 10.3389/fmicb.2017.01357

Loya, M. K., and Walsh, J. (2015). A Case of Community Acquired Pneumonia Caused by Hafnia alvei Developing Into an Empyema. Chest 148:101A. doi: $10.1378 /$ chest.2223426

Lu, J., Tian, Z., Yu, J., Yang, M., and Zhang, Y. (2018). Distribution and Abundance of Antibiotic Resistance Genes in Sand Settling Reservoirs and Drinking Water Treatment Plants across the Yellow River, China. Water 10, 1-12. doi: 10.3390/ w10030246

Luna-Guevara, J. J., Arenas-Hernandez, M. M. P., Martínez de la Peña, C., Silva, J. L., and Luna-Guevara, M. L. (2019). The Role of Pathogenic E. coli in Fresh Vegetables: Behavior, Contamination Factors, and Preventive Measures. Int. J. Microbiol. 2019:2894328. doi: 10.1155/2019/2894328

Madhavan, A., Balakrishnan, So, and Vasudevapanicker, J. (2018). Antibiotic susceptibility pattern of Shigella isolates in a tertiary healthcare center. J. Labor. Phys. 10, 140-144. doi: 10.4103/JLP.JLP

Mahapatra, A., Mahapatra, S., and Mahapatra, A. (2009). Escherichia fergusonii: An emerging pathogen in South Orissa. Indian J. Med. Microbiol. 23, 204-208. doi: 10.4103/0255-0857.16598

Malau, E., Ford, R., Valcanis, M., Jennison, A. V., Mosse, J., Bean, D., et al. (2018). Antimicrobial sensitivity trends and virulence genes in Shigella spp . from the Oceania region. Infect. Genet. Evolut. 64, 52-56. doi: 10.1016/j.meegid.2018.06. 015

Meng, L., Liu, H., Lan, T., Dong, L., Hu, H., Zhao, S., et al. (2020). Antibiotic Resistance Patterns of Pseudomonas spp. Isolated From Raw Milk Revealed by Whole Genome Sequencing. Front. Microbiol. 11:1005. doi: 10.3389/fmicb. 2020.01005

Minnullina, L., Pudova, D., Shagimardanova, E., Shigapova, L., Sharipova, M., and Mardanova, A. (2019). Comparative Genome Analysis of Uropathogenic Morganella morganii Strains. Front. Cell. Infect. Microbiol. 9, 1-14. doi: 10.3389/ fcimb.2019.00167

Mishra, M., Arukha, A. P., Patel, A. K., Behera, N., Mohanta, T. K., and Dhananjay Yadav. (2018). Multi-Drug Resistant Coliform: Water Sanitary Standards and Health Hazards. Front. Micro. 9, 1-8. doi: 10.3389/fphar.2018. 00311

Mitali, D., Mishra, S. S., Tripathy, R. C., and Dwivedi, B. K. (2018). Occurrence of Multiple Antibiotic Resistant E. coli on Surface Water of River Ganga at Allahabad, Uttar Pradesh, India. Oceanogr. Fisher. Open Access J. 8:555730. doi: 10.19080/ofoaj.2018.08.555730

Momtaz, H., Dehkordi, F. S., Hosseini, M. J., Sarshar, M., and Heidari, M. (2013). Serogroups, virulence genes and antibiotic resistance in Shiga toxin-producing Escherichia coli isolated from diarrheic and non-diarrheic pediatric patients in Iran. Gut Pathogens 5, 1-10. doi: 10.1186/1757-47495-39
Momtaz, H., Safarpoor Dehkordi, F., Taktaz, T., Rezvani, A., and Yarali, S. (2012). Shiga toxin-producing Escherichia coli isolated from bovine mastitic milk: serogroups, virulence factors, and antibiotic resistance properties. Scientif. World J. 2012:618709. doi: 10.1100/2012/618709

Monica, H., Dias, Y., Pai, M., and Raviglione, M. C. (2018). Antibioticresistant Enterobacteriaceae in healthy gut flora: A report from north Indian semiurban community. Indian J. Med. Res. 147, 217-220. doi: 10.4103/ijmr. IJMR

Morgan, H. D. R., Oxon, M. A., Eng, M. R. C. S., Lond, L. R. C. P., and Camb, D. P. H. (1906). Upon The Bacteriology of the Summer Diarrhoea of Infants. Br. J. 1, 908-912. doi: 10.1136/bmj.1.2364.908

Morris, S., and Cerceo, E. (2020). Trends, epidemiology, and management of multidrug resistant gram-negative bacterial infections in the hospitalized setting. Antibiotics 9, 1-20. doi: 10.3390/antibiotics9040196

Muringani, B. N. (2017). Antibiotic Susceptibility Patterns of E .Coli Isolated from Water and Stool Samples in Mthata Region Eastern Cape Province of South Africa. J. Bacteriol. Mycol. Open Acces. 3, 264-265. doi: 10.15406/jbmoa. 2016.03.00067

Murray, P. R., Baron, E. J., Jorgensen, J. H., Landry, M. L., and Pfaller, M. A. (eds) (2017). Mannual of Clinical Microbiology. 9th Editio. Washington, D. C: American Society for Microbiology.

Mustapha, A., and Imir, T. (2019). Detection of Multidrug-Resistance GramNegative Bacteria from Hospital Sewage in North East, Nigeria. Front. Environ. Microbiol. 5:1. doi: 10.11648/j.fem.20190501.11

Na, G., Lu, Z., Gao, H., Zhang, L., Li, Q., Li, R., et al. (2018). The effect of environmental factors and migration dynamics on the prevalence of antibioticresistant Escherichia coli in estuary environments. Scientif. Rep. 8, 1-9. doi: 10.1038/s41598-018-20077-x

Nahar, N., and Rashid, R B. (2018). Phylogenetic Analysis of the Antibiotic Resistance Genes in Salmonella Species in silico. J. Bioanalys. Biomed. 10, 1-12. doi: 10.4172/1948-593x.1000198

Obayiuwana, A., and Ibekwe, A. M. (2020). Antibiotic resistance genes occurrence in wastewaters from selected pharmaceutical facilities in Nigeria. Water 12:1897. doi: $10.3390 /$ w12071897

Obayiuwana, A., Ogunjobi, A., Yang, M., and Ibekwe, M. (2018). Characterization of bacterial communities and their antibiotic resistance profiles in wastewaters obtained from pharmaceutical facilities in lagos and Ogun states, Nigeria. Int. J. Environ. Res. Publ. Health 15:1365. doi: 10.3390/ijerph15071365

Obi, C. L., Green, E., Bessong, P. O., Villiers, B., De, Hoosen, A. A., et al. (2004). Gene encoding virulence markers among Escherichia coli isolates from diarrhoeic stool samples and river sources in rural Venda communities of South Africa. Water SA 30, 37-42.

Pal, M., Ayele, Y., Hadush, A., Panigrahi, S., and Jadhav, V. J. (2018). Air \& Water Borne Diseases Public Health Hazards Due to Unsafe Drinking Water. Air Water Borne Dis. 7, 1-6. doi: 10.4172/2167-7719.1000138

Parin, U., Kirkan, S., Arslan, S. S., and Yuksel, H. T. (2018). Molecular identification and antimicrobial resistance of Escherichia fergusonii and Escherichia coli from dairy cattle with diarrhoea. Veter. Med. 63, 110-116. doi: 10.17221/156/2017VETMED

Praveenkumarreddy, Y., Akiba, M., Guruge, K. S., Balakrishna, K., Vandana, K. E., and Kumar, V. (2020). Occurrence of antimicrobial-resistant escherichia coli in sewage treatment plants of south India. J. Water Sanit. Hygiene Devel. 10, 48-55. doi: 10.2166/washdev.2020.051

Pruss-Ustun, A., Bos, R., Gore, F., and Bartram, J. (2008). Safer water, better health: costs, benefits and sustainability of interventions to protect and promote health. Spain: World Health Organization.

Qadri, F., Svennerholm, A.-M., Faruque, A. S., and Sack, R. B. (2005). Enterotoxigenic Escherichia coli in Developing Countries: Epidemiology, Microbiology, Clinical Features, Treatment, and Prevention. Clin. Microbiol. Rev. 18, 465-483. doi: 10.1128/CMR.18.3.465

Ram, S., Vajpayee, P., and Shanker, R. (2007). Prevalence of multi-antimicrobialagent resistant shiga toxin and enterotoxin producing Escherichia coli in surface waters of river Ganga. Environ. Sci. Technol. 41, 7383-7388. doi: 10.1021/ es0712266

Ram, S., Vajpayee, P., Tripathi, U., Singh, R. L., Seth, P. K., and Shanker, R. (2008). Determination of antimicrobial resistance and virulence gene signatures in surface water isolates of Escherichia coli. J. Appl. Microbiol. 105, 1899-1908. doi: 10.1111/j.1365-2672.2008.03879.x 
Ranganathan, S., Doucet, M., Grassel, C. L., Delaine-elias, B., Zachos, N. C., and Barry, M. (2019). Evaluating Shigella flexneri Pathogenesis in the Human Enteroid Model. Infect. Immun. 87, 740-718e.

Ranjbar, R., Masoudimanesh, M., Dehkordi, F. S., Jonaidi-Jafari, N., and Rahimi, E. (2017). Shiga (Vero)-toxin producing Escherichia coli isolated from the hospital foods virulence factors, o-serogroups and antimicrobial resistance properties. Antimicrob. Resist. Infect. Contr. 6, 1-11. doi: 10.1186/s13756-016-0163-y

Ranjbar, R., Safarpoor Dehkordi, F., Sakhaei Shahreza, M. H., and Rahimi, E. (2018). Prevalence, identification of virulence factors, O-serogroups and antibiotic resistance properties of Shiga-toxin producing Escherichia coli strains isolated from raw milk and traditional dairy products. Antimicrob. Resist. Infect. Contr. 7, 1-11. doi: 10.1186/s13756-018-0345-x

Reza, R., Ali, S., and Farhad Safarpoor, D. (2019). Prevalence of Antibiotic Resistance and Distribution of Virulence Factors in the Shiga Toxigenic Escherichia coli Recovered from Hospital Food - ProQuest. Jundishapur J. Microbiol. 12, 1-8.

Robicsek, A., Strahilevitz, J., Sahm, D. F., Jacoby, G. A., and Hooper, D. C. (2006). qnr prevalence in ceftazidime-resistant Enterobacteriaceae isolates from the United States. Antimicrob. Agents Chemother. 50, 2872-2874. doi: 10.1128/ AAC.01647-05

Sambrook, J. F., and Russell, D. W. (2002). Molecular Cloning: A Laboratory Manual Sambrook, 3rd Edn. New York: Cold Spring Harbor Laboratory Press.

Sanderson, C. E., Fox, J. T., Dougherty, E. R., Cameron, A. D. S., and Alexander, K. A. (2018). The changing face of water: A dynamic reflection of antibiotic resistance across landscapes. Front. Microbiol. 9, 1-13. doi: 10.3389/fmicb.2018. 01894

Sandhu, R., Aggarwal, A., Sayal, P., and Kumar, S. (2019). Intestinal carriage of drug-resistant Gram-negative bacteria belonging to family Enterobacteriaceae in children aged 3-14 years: An emerging threat. Int. J. Health Allied Sci. 8, 108-115. doi: 10.4103/ijhas.IJHAS

Savino, F., Cordisco, L., Tarasco, V., Calabrese, R., Palumeri, E., and Matteuzzi, D. (2009). Molecular identification of coliform bacteria from colicky breastfed infants. Acta Paediatr. Int. J. Paediatr. 98, 1582-1588. doi: 10.1111/j.1651-2227. 2009.01419.x

Savino, F., Cordisco, L., Tarasco, V., Locatelli, E., Di Gioia, D., Oggero, R., et al. (2011). Antagonistic effect of Lactobacillus strains against gas-producing coliforms isolated from colicky infants. BMC Microbiol. 11:157. doi: 10.1186/ 1471-2180-11-157

Sayah, R. S., Kaneene, J. B., Johnson, Y., and Miller, R. (2005). Patterns of Antimicrobial Resistance Observed in Escherichia coli Isolates Obtained from Domestic- and Wild-Animal Fecal Samples, Human Septage, and Surface Water. Appl. Environ. Microbiol. 71, 1394-1404. doi: 10.1128/AEM.71.3. 1394

Shakya, P., Barrett, P., Diwan, V., Marothi, Y., Shah, H., Chhari, N., et al. (2013). Antibiotic resistance among Escherichia coli isolates from stool samples of children aged 3 to 14 years from Ujjain, India. BMC Infect. Dis. 13, 1-6. doi: 10.1186/1471-2334-13-477

Sidhu, J. P. S., Ahmed, W., Hodgers, L., and Toze, S. (2013). Occurrence of virulence genes associated with diarrheagenic pathotypes in Escherichia coli isolates from surface water. Appl. Environ. Microbiol. 79, 328-335. doi: 10.1128/ AEM.02888-12

Simkhada, P., Lamichhane, S., Subedi, S., and Shrestha, U. T. (2016). Bacteriological Profile and Antibiotic Susceptibility Pattern of Blood Culture Isolates from Patients Visiting Tertiary Care Bacteriological Profile and Antibiotic Susceptibility Pattern of Blood Culture Isolates from Patients Visiting Tertiary Care H. Glob. J. Inc 16, 1-9.

Singh, A. K., Das, S., Singh, S., Gajamer, V. R., Pradhan, N., Lepcha, Y. D., et al. (2018b). Prevalence of antibiotic resistance in commensal Escherichia coli among the children in rural hill communities of northeast India. PLoS One 13:e0199179. doi: 10.1371/journal.pone.0199179

Singh, A. K., Das, S., Singh, S., Gajamer, V., and Nilu, P. (2018a). First report on Bacterial Diversity of Potable Spring water of Indian Himalayan Region. BioRxiv [Preprint].

Singh, A. K., Das, S., Singh, S., Pradhan, N., Kumar, S., Gajamer, V. R., et al. (2019). Physicochemical Parameters and Alarming Coliform Count of the Potable Water of Eastern Himalayan State Sikkim: An Indication of Severe Fecal Contamination and Immediate Health Risk. Front. Publ. Health 7, 1-17. doi: 10.3389/fpubh.2019.00174
Singh, L., Cariappa, M. P., and Kaur, M. (2016). Klebsiella oxytoca: An emerging pathogen? Med. J. Arm. Forces India 72, S59-S61. doi: 10.1016/j.mjafi.2016.05. 002

Singh, N. K., Bezdan, D., Checinska Sielaff, A., Wheeler, K., Mason, C. E., and Venkateswaran, K. (2018c). Multi-drug resistant Enterobacter bugandensis species isolated from the International Space Station and comparative genomic analyses with human pathogenic strains. BMC Microbiol. 18, 1-13. doi: 10.1186/ s12866-018-1325-2

Skariyachan, S., Mahajanakatti, A. B., Grandhi, N. J., Prasanna, A., Sen, B., Sharma, N., et al. (2015). Environmental monitoring of bacterial contamination and antibiotic resistance patterns of the fecal coliforms isolated from Cauvery River, a major drinking water source in Karnataka. India Environ. Monitor. Assess. 187, 187-279. doi: 10.1007/s10661-015-4488-4

Stange, C., Sidhu, J. P. S., Tiehm, A., and Toze, S. (2016). Antibiotic resistance and virulence genes in coliform water isolates. Int. J. Hygiene Environ. Health 219, 823-831. doi: 10.1016/j.ijheh.2016.07.015

Subbiah, M., Caudell, M. A., Mair, C., Davis, M. A., Matthews, L., Quinlan, R. J., et al. (2020). Antimicrobial resistant enteric bacteria are widely distributed amongst people, animals and the environment in Tanzania. Nat. Commun. 11:228. doi: 10.1038/s41467-019-13995-5

Tagoe, D. N. A., Nyarko, H., Arthur, S. A., and Birikorang, E. (2011). A study of antibiotic susceptibility pattern of bacteria isolates in sachet drinking water sold in the cape cost metropolis of Ghana. Res. J. Microbiol. 6, 153-158.

Tambe, S., Kharel, G., Arrawatia, M. L., Kulkarni, H., Mahamuni, K., and Ganeriwala, A. K. (2012). Reviving dying springs: climate change adaptation experiments from the Sikkim Himalaya. Mount. Res. Devel. 32, 62-72. doi: 10.1659/MRD-JOURNAL-D-11-00079.1

Tambe, S., Kharel, G., Subba, S., and Arrawatia, M. L. (2013). Rural water security in the Sikkim Himalaya: status, initiatives and future strategy. Conf. Paper India Mount. Initiat. 32, 62-72.

Tobias, J., and Vutukuru, S. R. (2012). Simple and rapid multiplex PCR for identification of the main human diarrheagenic Escherichia coli. Microbiol. Res. 167, 564-570. doi: 10.1016/j.micres.2011.11.006

Vaz-Moreira, I., Egas, C., Nunes, O. C., and Manaia, C. M. (2013). Bacterial diversity from the source to the tap: A comparative study based on $16 \mathrm{~S}$ rRNA gene-DGGE and culture-dependent methods. FEMS Microbiol. Ecol. 83, 361-374. doi: 10.1111/1574-6941.12002

Vital, P. G., Zara, E. S., Paraoan, C. E. M., Dimasupil, M. A. Z., Abello, J. J. M., Santos, I. T. G., et al. (2018). Antibiotic Resistance and Extended-Spectrum Beta-Lactamase Production of Escherichia coli Isolated from Irrigation Waters in Selected Urban Farms in Metro Manila, Philippines. Water 10, 1-11. doi: 10.3390/w10050548

Vubil, D., Balleste-delpierre, C., Mabunda, R., Acácio, S., Garrine, M., Nhampossa, T., et al. (2018). Antibiotic resistance and molecular characterization of shigella isolates recovered from children aged less than 5 years in Manhiça, Southern Mozambique. Int. J. Antimicrob. Agents 51, 881-887. doi: 10.1016/j.ijantimicag. 2018.02.005

Wang, Y., Ma, Q., Hao, R., Zhang, Q., Yao, S., Han, J., et al. (2019). Antimicrobial resistance and genetic characterization of Shigella spp . in Shanxi Province, China, during 2006 - 2016. BMC Microbiol. 19:116. doi: 10.1186/s12866-0191495-6

Woo, P. C., Leung, P. K., and Leung, K. W. (2000). Identification by 16 S ribosomal RNA gene sequencing of an Enterobacteriaceae species from a bone marrow transplant recipient. Mol. Pathol. 53, 211-215. doi: 10.1136/mp.53.4.211

World Health Organisation (2018). Fact Sheet: Drinking-Water. Geneva: World Health Organization.

Conflict of Interest: The authors declare that the research was conducted in the absence of any commercial or financial relationships that could be construed as a potential conflict of interest.

Copyright (C) 2020 Singh, Das, Kumar, Gajamer, Najar, Lepcha, Tiwari and Singh. This is an open-access article distributed under the terms of the Creative Commons Attribution License (CC BY). The use, distribution or reproduction in other forums is permitted, provided the original author(s) and the copyright owner(s) are credited and that the original publication in this journal is cited, in accordance with accepted academic practice. No use, distribution or reproduction is permitted which does not comply with these terms. 